\title{
Potential of Deficit and Supplemental Irrigation under Climate Variability in Northern Togo, West Africa
}

\author{
Agossou Gadédjisso-Tossou ${ }^{1,2, *(\mathbb{C})}$, Tamara Avellán ${ }^{1}$ (1) and Niels Schütze ${ }^{2}$ (1) \\ 1 United Nations University Institute for Integrated Management of Material Fluxes and of \\ Resources (UNU-FLORES), Ammonstrasse 74, 01067 Dresden, Germany; avellan@unu.edu \\ 2 Institute of Hydrology and Meteorology, Technische Universität Dresden, 01069 Dresden, Germany; \\ niels.schuetze@tu-dresden.de \\ * Correspondence: Agossou.Gadedjisso-Tossou@tu-dresden.de; Tel.: +49-351-7999-3816
}

Received: 22 October 2018; Accepted: 4 December 2018; Published: 7 December 2018

\begin{abstract}
In the context of a growing population in West Africa and frequent yield losses due to erratic rainfall, it is necessary to improve stability and productivity of agricultural production systems, e.g., by introducing and assessing the potential of alternative irrigation strategies which may be applicable in this region. For this purpose, five irrigation management strategies, ranging from no irrigation (NI) to controlled deficit irrigation (CDI) and full irrigation (FI), were evaluated concerning their impact on the inter-seasonal variability of the expected yields and improvements of the yield potential. The study was conducted on a maize crop (Zea mays L.) at a representative site in northern Togo with a hot semi-arid climate and pronounced dry and wet rainfall seasons. The OCCASION (Optimal Climate Change Adaption Strategies in Irrigation) framework was adapted and applied. It consists of: (i) a weather generator for simulating long climate time series; (ii) the AquaCrop model, which was used to simulate the irrigation system during the growing season and the yield response of maize to the considered irrigation management strategies; and (iii) a problem-specific algorithm for optimal irrigation scheduling with limited water supply. We found high variability in rainfall during the wet season which leads to considerable variability in the expected yield for rainfed conditions (NI). This variability was significantly reduced when supplemental irrigation management strategies (CDI or FI) requiring a reasonably low water demand of about $150 \mathrm{~mm}$ were introduced. For the dry season, it was shown that both irrigation management strategies (CDI and FI) would increase yield potential for the local variety TZEE-W up to $4.84 \mathrm{Mg} /$ ha and decrease the variability of the expected yield at the same time. However, even with CDI management, more than $400 \mathrm{~mm}$ of water is required if irrigation would be introduced during the dry season in northern Togo. Substantial rainwater harvesting and irrigation infrastructures would be needed to achieve that.
\end{abstract}

Keywords: AquaCrop model; maize; deficit irrigation; crop-water production function; West Africa

\section{Introduction}

The present world population of 7.3 billion will increase to 9.7 billion by 2050 [1]. Similarly, the medium variant of the UN Population Division [2] predictions disclose that the total population of the West African region would increase from 350 million in 2015 to 450 million in 2030, and nearly 800 million in 2050. FAO [3] estimates that agricultural production will have to rise by $60 \%$ by 2050 to meet the world's projected demands for food and feed. In West Africa, Liniger et al. [4] reported that food production should increase by $70 \%$ by 2050 to meet the necessary caloric requirements. However, a lack of available water for agricultural production, the energy sector, and other forms of anthropogenic water consumption is already harming several parts of the world. This lack of water is projected to become more severe with the growing population, rising temperatures, and altering 
precipitation patterns [5]. The variation of the food diets in many developing countries compound this problem and lead to the demand for more processed food and animal proteins by consumers [6].

The World Bank [7] reports that the rate of increase in food demand is projected to be higher in developing than in developed countries. These are also the regions that are subject to a wide yield gap. The world demand (billion tons) of cereals was 1.20 in 1974, 1.84 in 1997 and is expected to be 2.50 in 2020 [8]. In addition, van Ittersum et al. [9] pointed out that Sub-Saharan Africa (SSA) is the region with lowest food security because by 2050 its demand for cereals will almost triple, whereas current levels of cereal consumption already rely on considerable importations.

Lobell and Gourdji [10] pointed out that, in the past several decades, air temperatures have been increasing in most of the main cereal cropping areas around the world. They added that the changes in temperature and the intensity and seasonal volume of rainfall are impacting soil moisture. In turn, soil moisture is of high importance for crop production. In developing countries, particularly, the changes in these climatic variables over time are likely to have a damaging impact on water accessibility, which in turn affects crop yield. Kotir [11] and Druyan [12] stressed the fact that researchers have described Sub-Saharan Africa as the most sensitive region to the impacts of climate variabilities and change because of its dependence on rainfed agriculture and low capacity for adaptation. Moreover, Sarr [13] contended that the West African region has faced decades of severe drought, which have affected agricultural production substantially. The observations already show the late onset and early cessation dates of rainfall and the reduction of length of growing period.

According to the Togolese Ministry of the Environment and Forestry (MERF) [14], in the dry savannah of northern Togo, a West African country, the wet season, which spanned six months in the 1970s, has reduced to five or four months nowadays. Consequently, on the one hand, a substantial amount of rainwater falls within a short period causing flooding, while, on the other hand, frequent dry spells in the wet season lead to crop failure [15]. In addition, there is no rainfed agricultural activity during the dry season in northern Togo because of a lack of rainfall [16].

Researchers and practitioners are putting more focus on producing more with limited resources in agriculture to meet the food demand and at the same time address the adverse effects of climate change [17-19]. Agriculture, which accounts for 38\% of Togo's gross domestic product, provides over $20 \%$ of export earnings and employs $70 \%$ of the active population. Togolese agriculture is predominantly rainfed [20,21]. According to the International Commission on Irrigation and Drainage (ICID) [22], rainfed agriculture is "agriculture without application of irrigation. It may be without, or with a drainage system." A promising practice to overcome water shortage in rainfed cropping systems is supplemental irrigation (SI). The ICID [22] defines SI as: "the addition of small amounts of water to essentially rainfed crops during times when rainfall fails to provide sufficient moisture for normal plant growth, in order to improve and stabilize yields." SI practice increases yields and water productivity in rainfed cropping systems [23]. In addition, conventional irrigation systems can be used to improve crop productivity. The ICID [22] defines conventional irrigation as: "the replenishment of soil water storage in plant root zone through methods other than natural precipitation".

Irrigation scheduling is the procedure of deciding when, where, and how much water to apply [24] for irrigation. Farmers can apply the total crop-water requirements or more in the right period if water is available. This practice is called full irrigation (FI). When water provisions are limited, or irrigation expenses are great, FI may be substituted by deficit irrigation (DI) [25]. This is limited irrigation scheduling in agriculture [26]. DI can be controlled or otherwise. Uncontrolled DI is equivalent to rainfed agriculture. English [27] and English and Raja [28] defined controlled deficit irrigation (CDI) as the concept of intentionally and systematically under-irrigating a crop. English [27] developed an analytical framework to evaluate the profit when optimizing water use. Thus, he included implicitly economic aspects in the definition. Later, Lecler [29] provided a more explicit definition: "CDI is an optimization strategy by which net returns are maximized by lessening the volume of irrigation water applied to a crop to a level that results in some yield loss caused by water stress". Recently, Fereres and Soriano [30] defined CDI as the application of water below full crop-water requirements 
or evapotranspiration. The objective of applying limited water is to cope with scarce water supplies and improve productivity. Kögler and Söffker [31] reported that CDI practice contributes to saving up to $20-40 \%$ irrigation water at yield reductions under $10 \%$. It can contribute to increasing farmers' net income where water is scarce [27]. Thus, CDI is an irrigation management practice that contributes to enhancing food security.

Many studies that applied the simulation-based approach to assess deficit irrigation strategies failed to consider the variability of relevant climate factors - such as precipitation and temperature-and soil properties [32,33]. Semenov [34] and Brumbelow and Georgakakos [35], among others, analyzed possible impacts of climate variability and climate change on agriculture using process-based simulation models. Most of these studies only look at rainfed or non-irrigated sites or assumed full irrigation. Few researchers, including Schütze and Schmitz [36] and Brumbelow and Georgakakos [35], assessed limited irrigation systems and the impact of climate variability on crop-water production functions (CWPF). Brumbelow and Georgakakos [35] derived probability distribution functions of CWPF (CWPF-PDs) using climate change scenarios data of the Intergovernmental Panel on Climate Change (IPCC). Schütze and Schmitz [36] delved into the CWPF concept and suggested a stochastic framework in the form of a decision support tool for Optimal Climate Change Adaption Strategies in Irrigation (OCCASION) for deriving site-specific stochastic CWPFs (SCWPFs). To perform such analyses, one needs to utilize crop models to simulate the potential or expected crop yield for a given soil, climate, and management practice condition.

Several crop simulation models such as DSSAT [37], AquaCrop [38-40], DAISY [41], CropWat [42], APSIM [43], and PILOTE [44] are available in the literature to simulate yield response to water. It is important to recognize that most of these models show substantial complexities and require several data to run. Most of these models require many parameters to run, and many are not readily available in the field and need to be determined experimentally [45]. Exceptionally, the AquaCrop model uses relatively few explicit and mostly intuitive parameters and input variables, requiring simple methods for their derivation [46]. For instance, unlike AquaCrop, the DSSAT model requires input data about crop genetics and pest management [37], while APSIM requires $\mathrm{NO}_{3}$ and $\mathrm{NH}_{4}$ content of the soil layers [43].

Few studies have investigated irrigation management strategies on crops in the dry savannah area of northern Togo [20]. Therefore, this study assessed the potential of deficit and supplemental irrigation in northern Togo. Specifically, the study aimed at: (i) characterizing the climate of a water-scarce site in northern Togo, West African region; and (ii) evaluating five irrigation management strategies, ranging from no irrigation (NI) to CDI and FI for a maize crop (Zea mays L.) at a representative site in northern Togo with pronounced dry and wet rainfall seasons.

\section{Materials and Methods}

\subsection{Study Area}

Togo is a small West African francophone country. It is bordered by the Bight of Benin and Burkina Faso in the south and north, respectively. Togo is bound in the west by Ghana and in the east by Benin. Geographically, it lies between latitudes $6^{\circ} \mathrm{N}$ and $11^{\circ} \mathrm{N}$, and longitudes $0^{\circ} \mathrm{E}$ and $2^{\circ}$ E. It covers a surface of $56,600 \mathrm{~km}^{2}$ and has a long, narrow profile, stretching more than $550 \mathrm{~km}$ from north to south but not exceeding $160 \mathrm{~km}$ in width [47]. Its population is estimated to be 6,191,155 [48].

We conducted this study in the Dapaong district, northern Togo (Figure 1). Dapaong belongs to the Southern-Guinea-Savannah agro-ecological zone [49]. The principal rainfed crops grown include maize (Zea mays), sorghum (Sorghum bicolor), and pearl millet (Pennisetum glaucum), mainly for subsistence, while cash crops such as cotton (Gossypium hirsutum) are also cultivated. Some vegetables and legumes such as okra (Abelmoschus esculentus), cowpea (Vigna unguiculata), and soybean (Glycine max) are grown in association with the cereals mentioned above. The vegetation type is a woody savannah, with noticeable agricultural farms. The primary tree species are Parkia biglobosa, Butyrospermum parkii, and 
Acacia sieberiana [50]. The Togolese Institute of Agricultural Research (ITRA) [51] and Didjeira et al. [52] identified maize crop as the staple food in Togo, and it represents $60 \%$ of the cereals consumed by the population. On the farms close to the houses, the main cropping system is intercropping (cereal-legume mixtures), while on the farms far from the houses, farmers practice monoculture [53]. Since cotton is grown with a high level of pesticides, intercropping is not possible on cotton farms. Hoes and cutlasses are the primary tools of cultivation.

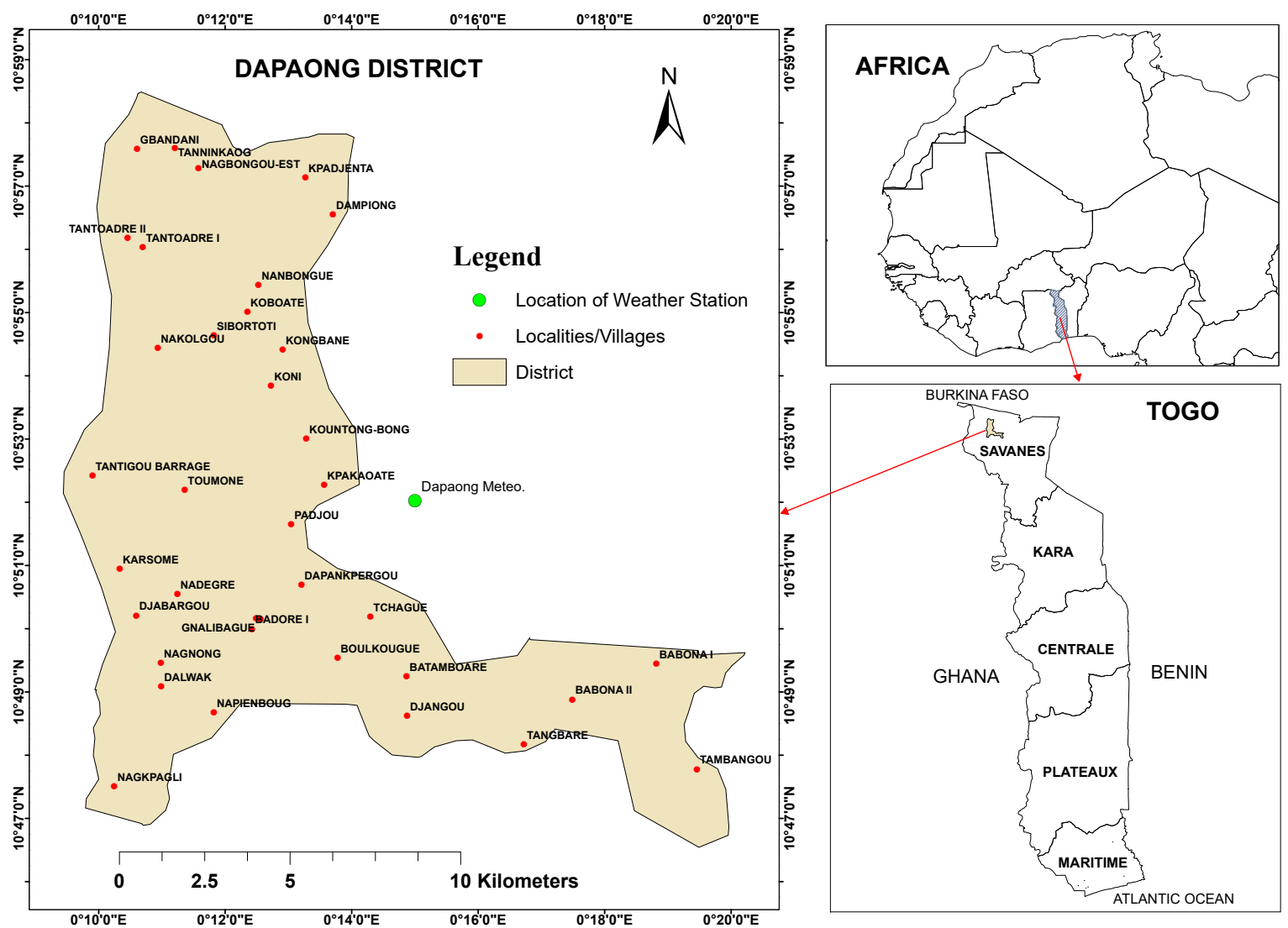

Figure 1. Map of northern Togo indicating the study area (Dapaong district).

According to Köppen-Geiger's climatic classification, the climate of Dapaong district is hot semi-arid (BSh) [54]. The period from mid-April to mid-October is humid, while in the other months dry conditions predominate in Dapaong. The months from June to September show high rainfall (Figure 2). These high annual values of rainfall are sufficient for rainfed cereal crops in northern Togo. The annual rainfall is, however, very unequally dispersed. From November to March (or sometimes April), there is practically no rainfall in the area. From May to October, a substantial amount of rainfall is recorded. Consequently, northern Togo is characterized by a single wet season in a year. This explains why farmers adopt intercropping to obtain the range of crops they need. Introducing irrigated crops in the dry season may help farmers to sustain their production. The mean annual temperature is $28.1^{\circ} \mathrm{C}$, and the annual total precipitation is $1050 \mathrm{~mm}$. The mean daily maximum temperature of the driest month is around $37^{\circ} \mathrm{C}$, whereas the mean daily minimum temperature of the wettest month is $20^{\circ} \mathrm{C}$ (Figure 2). In January and February, a robust dusty wind named harmattan, blowing in the northeast direction from the Sahara Desert, increases the dryness of the weather in the area [16]. 
Dapaong Station LONG 0.25 LAT 10.86 (330 m)

1980-2016 TOGO

28.1C $1050 \mathrm{~mm}$

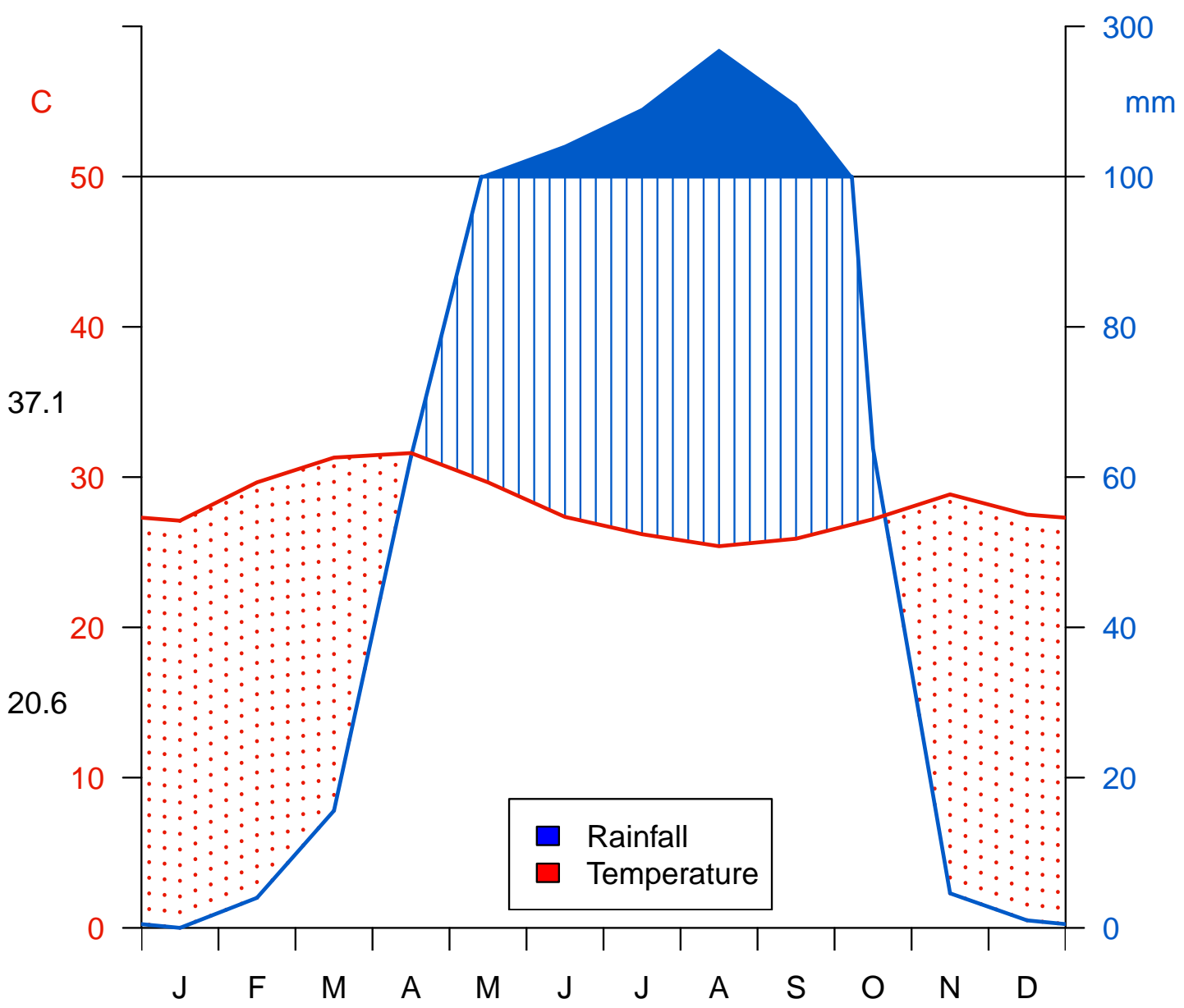

Figure 2. Walter-Lieth [55] climate diagram for northern Togo based on data collected at Dapaong Meteorological Station (Latitude: $10^{\circ} 51^{\prime} 44.10^{\prime \prime} \mathrm{N}$, Longitude: $0^{\circ} 12^{\prime} 27.43^{\prime \prime} \mathrm{E}$, Altitude: $330 \mathrm{~m}$ above sea level). Rainfall and temperature data were measured between 1980 and 2016.

With a population density of 96 inhabitants per $\mathrm{km}^{2}$, over $88 \%$ of the population live under the poverty line (US\$2/day) [56,57]. Complicated communal land tenure favors men, and encourages farm fragmentation. Women access only marginal lands characterized by reduced soil fertility. Most farmers are smallholders with less than 1.5 ha of land under cultivation [53]. Crop yields are generally low due to erratic rainfall, low soil fertility, low-quality seeds, and inappropriate land preparation tools, among others. Farmers' livelihood depends on small-scale farms with low input, and mixed crop-livestock agriculture. Regarding poultry, most farmers have local hens, cocks, and guinea fowls in their houses. Some families raise local dwarf goats and pigs [53].

\subsection{Methods}

\subsubsection{Adapted Framework for the Evaluation of Irrigation Management Alternatives}

In this study, we investigated five irrigation management strategies. These are NI, CDI for supplemental irrigation, CDI for conventional irrigation, FI for supplemental irrigation, and FI for conventional irrigation. The NI is equivalent to the rainfed system, the type of agriculture most farmers are practicing in Dapaong. When rainfall is unevenly distributed throughout the wet season, farmers have the option to apply an optimal amount of irrigation water to supplement the shortage (CDI for $\mathrm{SI}$ ) or use the fully required amount (FI for SI). On the other hand, in the dry season, farmers can 
deliberately apply an optimal amount of irrigation water (CDI for conventional irrigation) or fully irrigate the plants (FI for conventional irrigation). When combining these strategies with dry and wet seasons, we obtain the following: (i) NI for the wet season (WS-NI); (ii) CDI for supplemental irrigation system in the wet season (WS-CDI); (iii) full irrigation for supplemental irrigation system in the wet season (WS-FI); (iv) CDI for conventional irrigation system in the dry season (DS-CDI); and (v) full irrigation for conventional irrigation system in the dry season (DS-FI). In this study, one should bear in mind that we only dealt with the physiological and agronomical aspects of DI-crop response to different irrigation regimes-without any economic evaluation. The summary can be seen in Table 1 .

Table 1. Irrigation management strategies investigated.

\begin{tabular}{|c|c|c|c|c|c|}
\hline \multirow{3}{*}{ Type of Irrigation System } & \multicolumn{3}{|c|}{ Irrigation Management Strategies } & \multirow{2}{*}{\multicolumn{2}{|c|}{ Application Scenarios }} \\
\hline & \multicolumn{2}{|c|}{ Limited Supply } & \multirow{2}{*}{$\begin{array}{c}\text { Full Supply } \\
\text { Controlled }\end{array}$} & & \\
\hline & Uncontrolled & Controlled & & Wet Season (WS) & Dry Season (DS) \\
\hline No irrigation & NI & - & - & $x$ & - \\
\hline Supplemental irrigation & - & CDI & FI & $x$ & - \\
\hline Conventional irrigation & - & CDI & FI & - & $\mathrm{x}$ \\
\hline
\end{tabular}

The OCCASION framework was adapted and used to assess the five irrigation management strategies mentioned above (Figure 3). The adapted framework consists of: (i) a weather generator for simulating long climate time series; (ii) the AquaCrop model, which was used to simulate the irrigation system during the growing season and the yield response of maize to the considered irrigation management strategies (Figure 3, Loop 1); and (iii) a problem-specific algorithm for optimal irrigation scheduling with limited water supply (Figure 3, Loop 2). The latter is named Global Evolutionary Technique for OPTimal Irrigation Scheduling (GET-OPTIS) (For more details, see [33]). A range of given maximum volumes of water is then assigned; a complete CWPF can be derived. The produced CWPF characterizes the maximum yields that can be attained with a given amount of water and is designated the potential CWPF. Then, the crop simulation model was run for a long-term climate time series data yielding a necessary amount of CWPFs. Also, optimized irrigation schedules are obtained. Subsequently, the resulting CWPFs were analyzed, and the SCWPFs obtained through parameters of descriptive statistics such as mean, median, and probability of exceedance, among others. SCWPFs are empirical probability functions where, for every volume of applied irrigation water, the marginal distribution function of the yield related to it can be derived. The probability of exceedance represents the reliability that a specific yield can be achieved [32].

\subsubsection{Processing of Climate Data and Set-Up of the LARS Weather Generator}

Historical weather observations, including daily maximum temperature, daily minimum temperature, daily rainfall, daily wind speed, daily minimum humidity, and daily maximum humidity were obtained from the nearest meteorological station to the study site-courtesy of the National Weather Service of Togo. These daily weather data available at the station range from 1983 to 2011. In addition, the observed monthly rainfall and maximum and minimum temperatures data from 1980 to 2016 were provided. These monthly data were utilized to characterize the climate of northern Togo with the climate diagram of Walter and Lieth [55]. The Dapaong meteorological station is located at latitude $10^{\circ} 51^{\prime} 44.10^{\prime \prime} \mathrm{N}$, longitude $0^{\circ} 12^{\prime} 27.43^{\prime \prime} \mathrm{E}$, and altitude $330 \mathrm{~m}$ above sea level (Figure 1 ). The solar radiation data, as well as sunshine hours data, were not available at Dapaong weather station. As a substitute, the uncorrected gridded incident solar radiation from the Prediction of Worldwide Energy Resource dataset from the National Aeronautics and Space Administration project NASA-POWER [58] was utilized. Van Wart et al. [59] showed that NASA-POWER is a good source of climate data for crop yields simulation studies. It is publicly accessible, shows acceptable general agreement with ground data for incident solar radiation, and has been used by similar previous studies (See Section 2.2.4). 


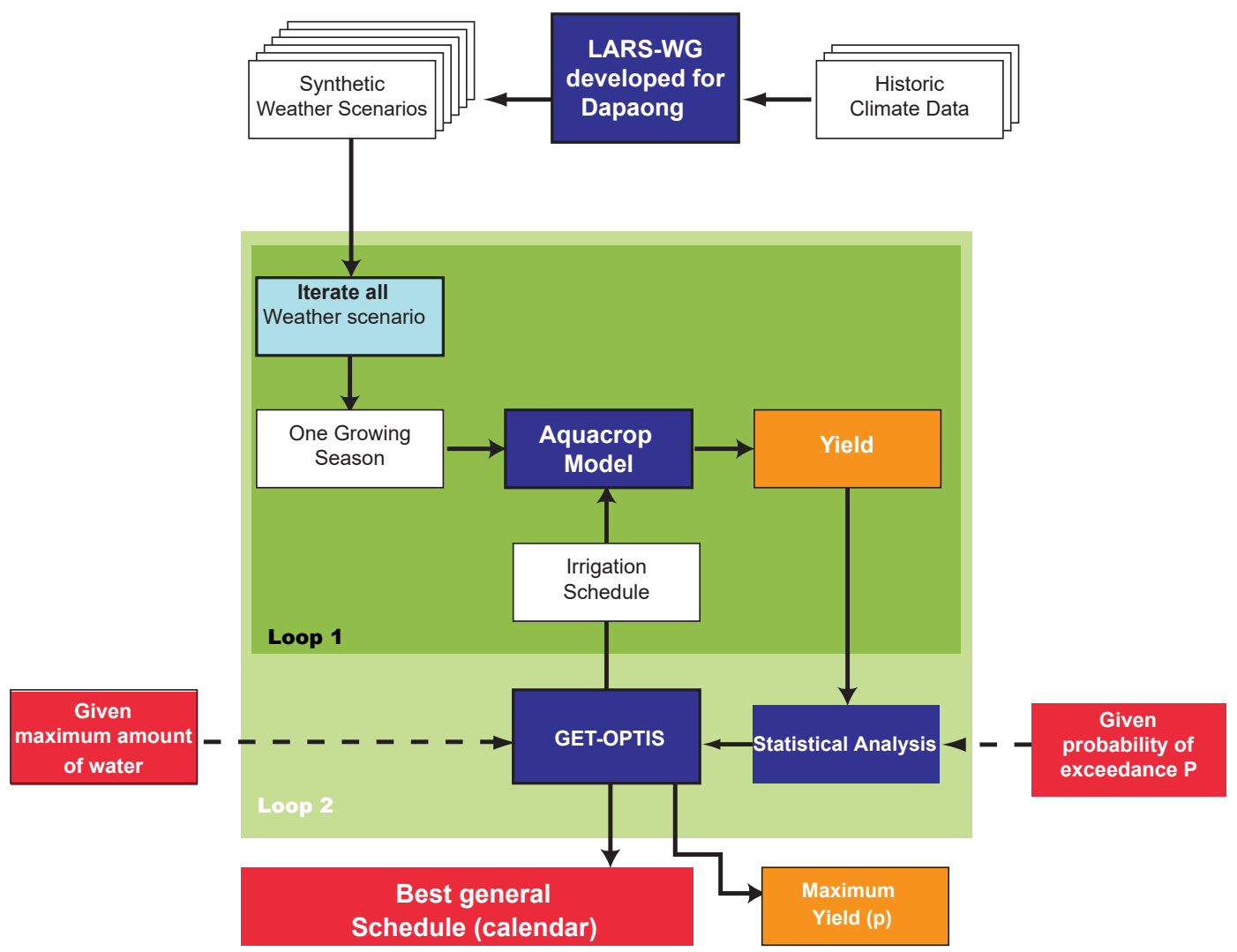

Figure 3. General framework for generating stochastic crop water production functions (adapted from Schütze and Schmitz [36]).

Since the 29-year period (1983-2011) of weather data is not long enough to be used in the assessment of climate variability effect on crop yield, the Long Ashton Research Station Weather Generator version 4.0 (LARS-WG) - a stochastic weather generator-was used to generate a 100-year period of near future climate data. In this study, out of the existing weather generators, LARS-WG was used for two reasons. Firstly, it uses more complex distributions for weather variables and has been tested for diverse climates and found to be better than some other weather generators such as WGEN [60] (Appendix A). Secondly, Semenov [61] recently tested LARS-WG at different locations across the world and revealed its ability to model rainfall extremes with acceptable performance. Similarly, Mehan et al. [62] provided insights into the suitability of LARS-WG for use with water resource applications. Guo et al. [63] suggested performing more than a single realization when generating weather data using LARS-WG for hydrologic and environmental applications. We assessed the performance of the LARS-WG in simulating weather data of Dapaong by comparing the observed and the simulated data with the Kolmogorov-Smirnov test (KS-test). We used the KS-test for the comparison of the probability distributions for each month. The KS-test is a non-parametric and distribution-free test that tries to determine if two datasets are extensively different and come from different distributions. It is an alternative to the Chi-square goodness of fit test. The KS-test compares the two empirical distribution functions as in Equation (1) [64].

$$
\mathrm{D}=\left|\mathrm{E}_{1}(\mathrm{i})-\mathrm{E}_{2}(\mathrm{i})\right|
$$

where $E_{1}$ and $E_{2}$ represent the empirical distribution functions of the two distributions, and $D$ is the absolute difference between them.

The KS-test examines for changes in distributions coming from the generated and observed weather. The KS-test calculates a test statistic and an equivalent $p$-value [65]. It shows how likely it is that the generated and observed data originate from the same distribution. If the $p$-value is very 
low and below the significance level, set to 0.01 or 0.05 , the simulated climate is unlikely to be the same as the "true" climate. Although a $p$-value of 0.05 is the standard significance level employed in most statistics, the authors of the LARS-WG model recommended that a $p$-value of 0.01 should be considered as the satisfactory significance level.

The calibrated LARS-WG for Dapaong was then used to forecast the 100-year daily rainfall and temperature data mentioned above for a near future. For this, the outputs of the General Circulation Models (GCMs) HADCM3 (Hadley Centre Coupled Model version 3) of the IPCC Special Report on Emission Scenarios (SRES) A2 were inputted into LARS-WG. The HADCM3 is the product of the UK Meteorological Office, gridded as $2.5^{\circ} \times 3.75^{\circ}$. These long-term data were used to run the AquaCrop model to assess the five irrigation management strategies.

\subsubsection{Description and Set-Up of the Crop Simulation Model}

AquaCrop, a water-driven crop simulation model, was developed in 2009 by the Food and Agriculture Organization (FAO) of the United Nations [38-40]. The development of the AquaCrop model is based on the algorithm of yield response to water in FAO Irrigation and Drainage Paper No. 33 [66]. AquaCrop evolves from the previous Doorenbos and Kassam [66] $\mathrm{K}_{\mathrm{y}}$ approach (Equation (2)), where relative evapotranspiration (ET) is pivotal in calculating yield.

$$
\frac{\left(\mathrm{Y}_{\mathrm{x}}-\mathrm{Y}_{\mathrm{a}}\right)}{\mathrm{Y}_{\mathrm{x}}}=\mathrm{K}_{\mathrm{y}}\left[\frac{\left(\mathrm{ET}_{\mathrm{x}}-\mathrm{ET}_{\mathrm{a}}\right.}{\mathrm{ET}_{\mathrm{x}}}\right]
$$

where $Y_{x}$ and $Y_{a}$ are the maximum and actual yield, respectively; $\mathrm{ET}_{\mathrm{x}}$ and $\mathrm{ET}_{\mathrm{a}}$ are the maximum and actual evapotranspirations, respectively; and $\mathrm{K}_{\mathrm{y}}$ is the proportionality factor between relative yield loss and relative reduction in evapotranspiration.

AquaCrop simulates crop yield in four steps: crop development, crop transpiration, biomass formation, and yield formation [40]. Four water stress response coefficients are considered in the model. These are related to canopy expansion, stomatal conductance, canopy senescence, and harvest index [67].

\subsubsection{Soil Data and Calibration of the Crop Simulation Model}

We retrieved the physical characteristics data of soils in Dapaong from Poss [68]. These measured soil physical characteristics were used as input into the Soil Water Hydraulic Properties Calculator (http://hydrolab.arsusda.gov/soilwater/Index.htm) to compute various soil hydraulic parameters required to run AquaCrop. We used this soil water hydraulic properties calculator because it has been employed in previous studies in the West African region (e.g., Akumaga et al. [69]). These include volumetric soil water content at field capacity, permanent wilting point, saturation, and saturated hydraulic conductivity (Table 2). Poss [68] classified the soil of Dapaong as sandy loam. According to the World Reference Base for Soil Resources, the soil in northern Togo is characterized Dystric-Ferric Luvisols [70,71].

Table 2. The soil description and properties of Dapaong (See Poss [68]).

\begin{tabular}{|c|c|c|c|c|c|c|c|c|c|c|}
\hline \multirow[b]{2}{*}{ Soil Depth (cm) } & \multicolumn{3}{|c|}{ Texture } & \multirow[b]{2}{*}{$\begin{array}{l}\text { OM } \\
(\%)\end{array}$} & \multirow[b]{2}{*}{$\underset{(\mathrm{g} / \mathrm{cm})}{\mathrm{dB}}$} & \multirow[b]{2}{*}{$\begin{array}{c}\text { SAT } \\
(\text { Vol. \%) }\end{array}$} & \multirow[b]{2}{*}{$\begin{array}{c}\text { FC } \\
(\text { Vol. \%) }\end{array}$} & \multirow[b]{2}{*}{$\begin{array}{c}\text { PWP } \\
\text { (Vol.\%) }\end{array}$} & \multirow[b]{2}{*}{$\begin{array}{c}\text { Ksat } \\
\text { (mm/da) }\end{array}$} & \multirow[b]{2}{*}{ Textural Class } \\
\hline & $\begin{array}{c}\text { Sand } \\
(\%)\end{array}$ & $\begin{array}{l}\text { Silt } \\
(\%)\end{array}$ & $\begin{array}{l}\text { Clay } \\
(\%)\end{array}$ & & & & & & & \\
\hline $20-50$ & 72.0 & 19.0 & 9.0 & 0.9 & 1.6 & 40.8 & 13.5 & 5.9 & 503.0 & Sandy Loam \\
\hline $50-110$ & 66.5 & 18.0 & 15.5 & 0.7 & 1.6 & 39.9 & 18.3 & 10.0 & 239.5 & Sandy Loam \\
\hline
\end{tabular}

Regarding the crop parameters, some of them were assumed to be conservative. The values of conservative parameters used in our study are the same as values proposed by FAO [72] (not presented here). The others, non-conservative or crop-specific, were estimated using measured data retrieved from the ITRA [51], Didjeira et al. [52], and Worou and Saragoni [73] studies conducted in northern Togo (Table 3). These data were used to fine-tune the maize parameters to the local agronomic 
and management conditions of the study area before running the simulations in AquaCrop. These parameters include information about sowing, canopy cover, canopy senescence, flowering, rooting depth, harvest index, soil management, and the maize cultivar used. Regarding the calibration of the canopy cover, we used the options in AquaCrop to estimate the initial canopy cover (CCo) from sowing rate, seed weight, seed number and estimated germination rate. Subsequently, the canopy expansion rates were automatically estimated by AquaCrop after we entered the phenological dates such as dates of emergence, maximum canopy cover, senescence and maturity. The AquaCrop model simulations were run in growing degree day (GDD) calculated from temperature data used as climate input. Geerts et al. [74], Salemi et al. [75], and Silvestro et al. [76] reported on the most sensitive parameters in AquaCrop obtained through sensitivity analysis testing. The essential crop-specific parameters used to calibrate the AquaCrop model for simulating maize growth and productivity for the study area are presented in Table 3. It should be noted that the calibration of AquaCrop model in this study is preliminary, thus the conclusions that emanated from the simulations are qualitative. The main idea was to compare the irrigation management strategies assessed in this study qualitatively.

Table 3. Non-conservative parameters adjusted and agronomic information for Dapaong, Togo.

\begin{tabular}{|c|c|c|}
\hline Parameter Description & Value & Units or Meaning \\
\hline Time from sowing to emergence & $7(135)$ & DAP(GDD) \\
\hline Time to maximum canopy cover & $60(1109)$ & DAP(GDD) \\
\hline Time from sowing to maximum rooting depth & $67(1257)$ & DAP(GDD) \\
\hline Time from sowing to start of canopy senescence & $76(1408)$ & DAP(GDD) \\
\hline Time from sowing to maturity & $100(1898)$ & DAP(GDD) \\
\hline Time from sowing to flowering & $54(1018)$ & DAP(GDD) \\
\hline Duration of flowering & $10(183)$ & DAP(GDD) \\
\hline Length of building up HI & $42(778)$ & DAP(GDD) \\
\hline Maximum effective rooting depth, $\mathrm{Z}$ & 1 & meter \\
\hline Minimum effective rooting depth, $\mathrm{Zn}$ & 0.3 & meter \\
\hline Reference harvest index, HI & 50 & $\%$ \\
\hline Cultivar (TZEE-W) & - & TZEE-W \\
\hline Planting method & - & Direct sowing \\
\hline Planting density & 62,500 & Plants/ha \\
\hline Soil fertility & 65 & Moderate (\%) \\
\hline Surface mulches & 0 & $\%$ \\
\hline Curve number, CN & 66 & - \\
\hline Readily Evaporable water, REW & 2 & $\mathrm{~mm}$ \\
\hline
\end{tabular}

DAP, days after planting; GDD, growing degree days; HI, harvest index.

Table 4 summarizes the potential and selected sources of the input data used in this study and reasons for selecting these specific sources.

Table 4. Input data sources.

\begin{tabular}{|c|c|c|c|}
\hline Type of Data & Possible Sources & Selected Sources for the Study & $\begin{array}{l}\text { Reasons of Selecting Specific } \\
\text { Sources for the Study }\end{array}$ \\
\hline $\begin{array}{l}\text { Temperature, rainfall, wind } \\
\text { speed, and humidity }\end{array}$ & $\begin{array}{l}\text {-Local meteorological station } \\
\text {-Observed data online (NOAA, etc.) } \\
\text {-Satellite data (NASA, etc.) }\end{array}$ & Local meteorological station & $\begin{array}{l}\text { Observed data with no } \\
\text { missing values }\end{array}$ \\
\hline $\begin{array}{l}\text { Solar radiation and } \\
\text { sunshine hours }\end{array}$ & $\begin{array}{l}\text {-Observed data online (NOAA, } \\
\text { etc.) } \\
\text {-Satellite data (NASA, etc.) }\end{array}$ & $\begin{array}{c}\text { Satellite data } \\
\text { (NASA-POWER project) }\end{array}$ & $\begin{array}{c}\text { Publicly accessible, shows } \\
\text { acceptable general agreement } \\
\text { with ground data }\end{array}$ \\
\hline $\begin{array}{l}\text { Crop data: } \\
\text { conservative parameters }\end{array}$ & AquaCrop manual & AquaCrop manual & In line with AquaCrop model \\
\hline
\end{tabular}




\subsubsection{Optimal Irrigation Scheduling with Limited Water Supply}

Matlab, AquaCrop interface, and Plugin-ACsaV40 (version 4; http:/ / www.fao.org/aquacrop/ en/) were used to simulate multiple projects for successive years. The soil and crop phenological data described in Tables 2 and 3, respectively, were used to calibrate AquaCrop. First, AquaCrop was run for a given amount of irrigation water for the maize crop under a specific climate scenario during the dry season of the Dapaong area. GET-OPTIS was employed as irrigation scheduling optimizer and crop yield maximizer. Then, we iterated over a range of given water volumes. As a result, a complete crop-water production function (CWPF) was derived. The 100-year maize crop simulations were run for the wet season as well as the dry season to assess the irrigation management strategies described above, in northern Togo.

\section{Results and Discussion}

\subsection{Traits of the Climate in Dapaong}

The temperature is high during the dry season reaching $37^{\circ} \mathrm{C}$ and $26^{\circ} \mathrm{C}$ maximum and minimum temperatures, respectively, while, in the wet season, the maximum temperature is $30^{\circ} \mathrm{C}$ and the minimum temperature is close to $26^{\circ} \mathrm{C}$ (Figure 4a). Due to these high temperatures, especially in the dry season, it is likely that the evapotranspiration is relatively high in the area. This argument is corroborated by Djaman and Ganyo [77] who found that the potential annual reference evapotranspiration-computed using the FAO-56 Penman-Monteith method-in northern Togo is higher than $1800 \mathrm{~mm}$ on average.
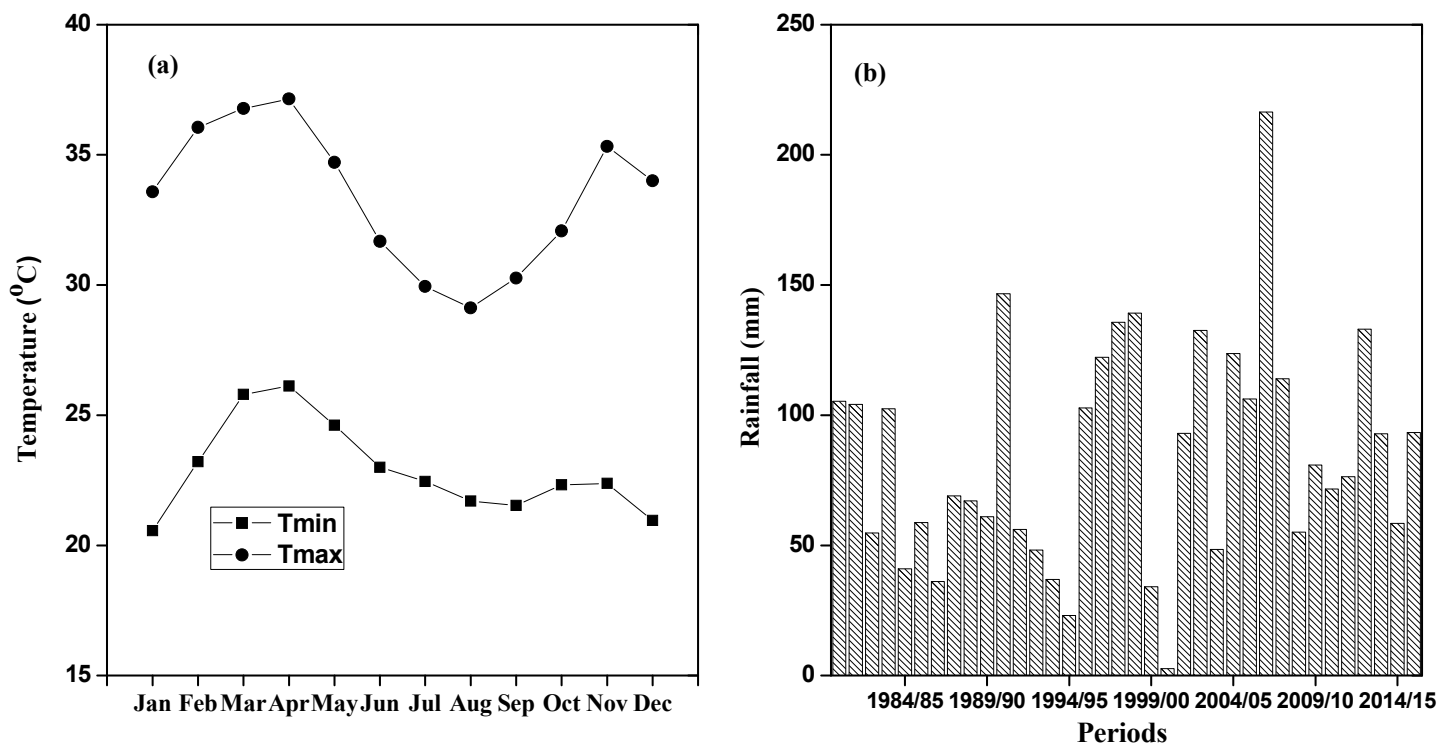

Figure 4. (a) Monthly mean temperature; and (b) mean total rainfall from November to April in Dapaong, Togo (1980-2016).

Figure $4 \mathrm{~b}$ depicts the mean total rainfall during the dry season (November-April) in Dapaong district. The rainfall recorded during the dry season varies significantly from year to year. On average, the total rain that falls within this period is lower than $85 \mathrm{~mm}$. In some years, the volume of rain which falls in the same period is up to $100 \mathrm{~mm}$. The highest amount was reached in 2006/2007 (216 mm). Globally, this rainfall occurs on an average of five days only. Thus, none of the main cereals grown in the area such as maize, millet, and sorghum can survive under the dry season climatic conditions without an additional water supply. These findings prove again the fact that farmers only grow crops during the wet season. Overall, the climate of Dapaong in northern Togo is unfavorable to agricultural activities throughout the year because of its vagaries and uncertainties compromising crop yield. These results are in agreement with studies by Ogounde and Abotchi [16]. 


\subsection{Validation and Application of the LARS Weather Generator}

The LARS-WG model showed robust compliance between observed and simulated data for the maximum as well as minimum temperatures (Table 5). These findings showed no significant differences between the observed and simulated temperatures for all months. All $p$-values were close to one. It means that the observed and simulated data were from the same distribution. Therefore, based on these results, we conclude that the performance of the LARS-WG model in simulating the climatic variables such as minimum and maximum temperatures of Dapaong district is satisfactory. Similar results were obtained by Semenov et al. [60] at 18 sites in the USA and Europe. However, the standard deviations of the monthly mean simulated values are less than half of the standard deviations of observed values for all months. This means that the extreme temperature values in the minimum and maximum temperatures simulated are smaller than in the observed data.

The observed and simulated rainfall values for most of the months do not correlate significantly (Table 5). This result agrees with studies by Osman et al. [78] in Iraq. However, there are significant differences between December and January, when LARS-WG was incapable of reproducing the observed rainfall, partly because these periods are the driest during the dry season. The standard deviations of the monthly mean rainfall of observed and predicted values are similar for January, February, and April (Table 5). These results imply that there are fewer extreme rainfall values in the dry months, which are of our interest in this study. Overall, the performance of LARS-WG in predicting the rainfall of the Dapaong area is at an acceptable level. It means that the quality of the long-term data that were generated based on these calibration results is not affected.

\subsection{Evaluation of Irrigation Management Strategies}

\subsubsection{Wet Season—Rainfed and Supplemental Irrigation Systems}

\section{> Maize Crop under Rainfed Conditions (WS-NI)}

While Figure 5a shows the results of the expected maize crop yields that can be achieved during the rainfed cropping system, Figure $5 \mathrm{~b}$ portrays the rainfall statistics within the same period. The volume of rainwater that falls within the cropping period of the wet season in Dapaong ranges from $450 \mathrm{~mm}$ to $1100 \mathrm{~mm}$ approximately. The frequency of the rainfall is high, between $600 \mathrm{~mm}$ and $900 \mathrm{~mm}$ (Figure $5 b$ ). The distribution of the expected rainfed yields is moderately skewed left with a higher coefficient in absolute values (1.91) (Figure 5a). The standard deviation of the expected yields obtained under rainfed conditions is higher than in the case of irrigated maize, regardless of the volume of water used, in northern Togo (See Section 3.3.2). These results show that the variability, as well as the uncertainty, in the yields, are higher under the rainfed conditions (WS-NI) than under the dry season CDI and FI. The high variability under rainfed conditions is likely due to inadequate rainfall distribution and dry spells in the wet season [79]. On average, the expected maize crop yield achieved in the wet season is $3.5 \mathrm{Mg} / \mathrm{ha}$ (Figure $5 \mathrm{a}$ ). These results agree with the findings by Didjeira et al. [52] who indicated the range of $3.5-5 \mathrm{Mg} / \mathrm{ha}$ as the expected yield for the maize variety used in this study. Similarly, these results are in line with that of Fosu-Mensah [80] who reported that, in sub-humid Ghana under projected climate change (2030-2050) for scenario A1B of IPCC, the rainfed maize grain yield varies from $3.16 \mathrm{Mg} / \mathrm{ha}$ to $4.09 \mathrm{Mg} / \mathrm{ha}$. Therefore, the calibrated AquaCrop model in this study performs well. These results can be improved if data on more site-specific parameters are made available. Akumaga et al. [69] suggested that the AquaCrop model can be utilized as a tool in the study and modeling of maize productivity in West African region. 
Table 5. Kolmogorov-Smirnov test statistics for rainfall, maximum and minimum temperatures in Dapaong.

\begin{tabular}{|c|c|c|c|c|c|c|c|c|c|c|c|c|}
\hline \multirow{2}{*}{ Month } & \multicolumn{4}{|c|}{ RAINFALL } & \multicolumn{4}{|c|}{ MAXIMUM TEMPERATURE } & \multicolumn{4}{|c|}{ MINIMUM TEMPERATURE } \\
\hline & SD of Observed Data & SD of Simulated Data & K-S & $p$-Value & SD of Observed Data & SD of Simulated Data & K-S & $p$-Value & SD of Observed Data & SD of Simulated Data & K-S & $p$-Value \\
\hline January & 0.11 & 0.17 & 0.57 & 0.00 & 1.34 & 0.46 & 0.11 & 1.00 & 1.60 & 0.52 & 0.05 & 1.00 \\
\hline February & 14.89 & 13.89 & 0.17 & 0.84 & 1.24 & 0.41 & 0.16 & 0.91 & 1.66 & 0.48 & 0.11 & 1.00 \\
\hline March & 19.53 & 31.90 & 0.15 & 0.94 & 0.73 & 0.28 & 0.11 & 1.00 & 1.04 & 0.36 & 0.16 & 0.91 \\
\hline April & 44.99 & 43.27 & 0.11 & 1.00 & 0.95 & 0.43 & 0.11 & 1.00 & 0.84 & 0.43 & 0.11 & 1.00 \\
\hline May & 38.39 & 44.09 & 0.05 & 1.00 & 1.25 & 0.40 & 0.11 & 1.00 & 0.83 & 0.38 & 0.11 & 1.00 \\
\hline June & 54.58 & 53.28 & 0.03 & 1.00 & 0.89 & 0.32 & 0.05 & 1.00 & 0.72 & 0.30 & 0.05 & 1.00 \\
\hline July & 69.68 & 85.13 & 0.05 & 1.00 & 0.72 & 0.37 & 0.05 & 1.00 & 0.57 & 0.26 & 0.05 & 1.00 \\
\hline August & 85.44 & 99.96 & 0.06 & 1.00 & 0.60 & 0.30 & 0.05 & 1.00 & 0.57 & 0.26 & 0.11 & 1.00 \\
\hline September & 61.77 & 68.39 & 0.08 & 1.00 & 0.58 & 0.37 & 0.05 & 1.00 & 0.58 & 0.25 & 0.05 & 1.00 \\
\hline October & 43.20 & 57.00 & 0.01 & 1.00 & 1.04 & 0.40 & 0.11 & 1.00 & 0.83 & 0.27 & 0.05 & 1.00 \\
\hline November & 12.00 & 15.73 & 0.13 & 0.98 & 0.83 & 0.26 & 0.11 & 1.00 & 1.34 & 0.34 & 0.11 & 1.00 \\
\hline December & 5.66 & 10.98 & 0.26 & 0.36 & 1.04 & 0.43 & 0.05 & 1.00 & 1.38 & 0.44 & 0.05 & 1.00 \\
\hline
\end{tabular}
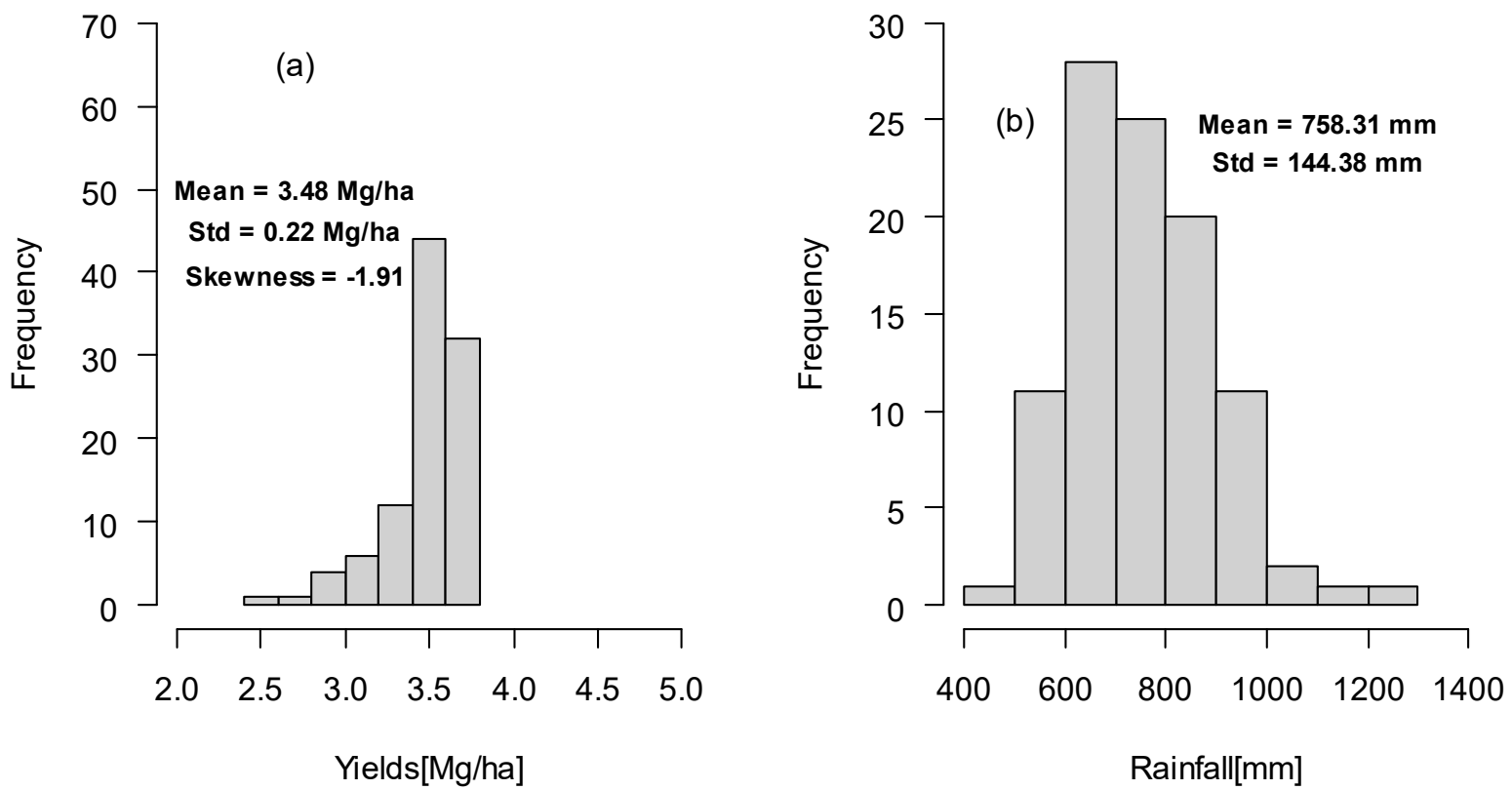

Figure 5. Histogram of distributions of: (a) expected yield of maize grown in a rainfed system (WS-NI); and (b) the rainfall during the wet season in Dapaong. 


\section{$>$ Maize under Supplemental Irrigation (WS-CDI and WS-FI)}

To improve yield while reducing its variability at the same time, one may apply supplemental irrigation during the rainfed cropping system whenever the crops are experiencing severe water stress, and rainfall is not occurring. The stochastic crop-water production functions for supplemental irrigation conditions are shown in Figure 6a. It can be hypothesized that, when more than $150 \mathrm{~mm}$ supplemental irrigation water is applied, the variation in the resulting expected crop yield is likely due to the variation of temperature and radiation in the area. These assumptions are supported by the nearly symmetric distributions of the corresponding expected crop yields (Figure 6a). Besides, at volumes of supplemental water lower than $150 \mathrm{~mm}$, the variation in the expected crop yield can result from the combined effects of the uneven distribution of rainfall and the climate parameters mentioned above. The $90 \%$ of SCWPF exceedance probability of yield achievement seems to be the best option for enhancing food security in northern Togo. This might be because it is the only option which helps to achieve the highest level of crop yield improvement (15\% or more) (Figure 6a). Applying supplemental irrigation in northern Togo for maize crop cultivation will not only contribute to improving crop grain yield and enhancing food security [81-83] but also help to improve farmers' livelihood. Nevertheless, supplemental irrigation alone cannot improve the rainfed yields significantly; it needs to be combined with other field management aspects such as soil preparation and fertility, pests and diseases management, and the choice of suitable crop varieties. It can be concluded that CWPF is a useful planning tool to assess water requirement for crops, especially in water-scarce regions. Heng et al. [84] and Stricevic et al. [85] reported that, due to its sufficient degree of simulation accuracy, the AquaCrop model is a valuable tool for estimating crop productivity under rainfed conditions, deficit and supplemental irrigation, and on-farm water management strategies for improving the efficiency of water use in agriculture.
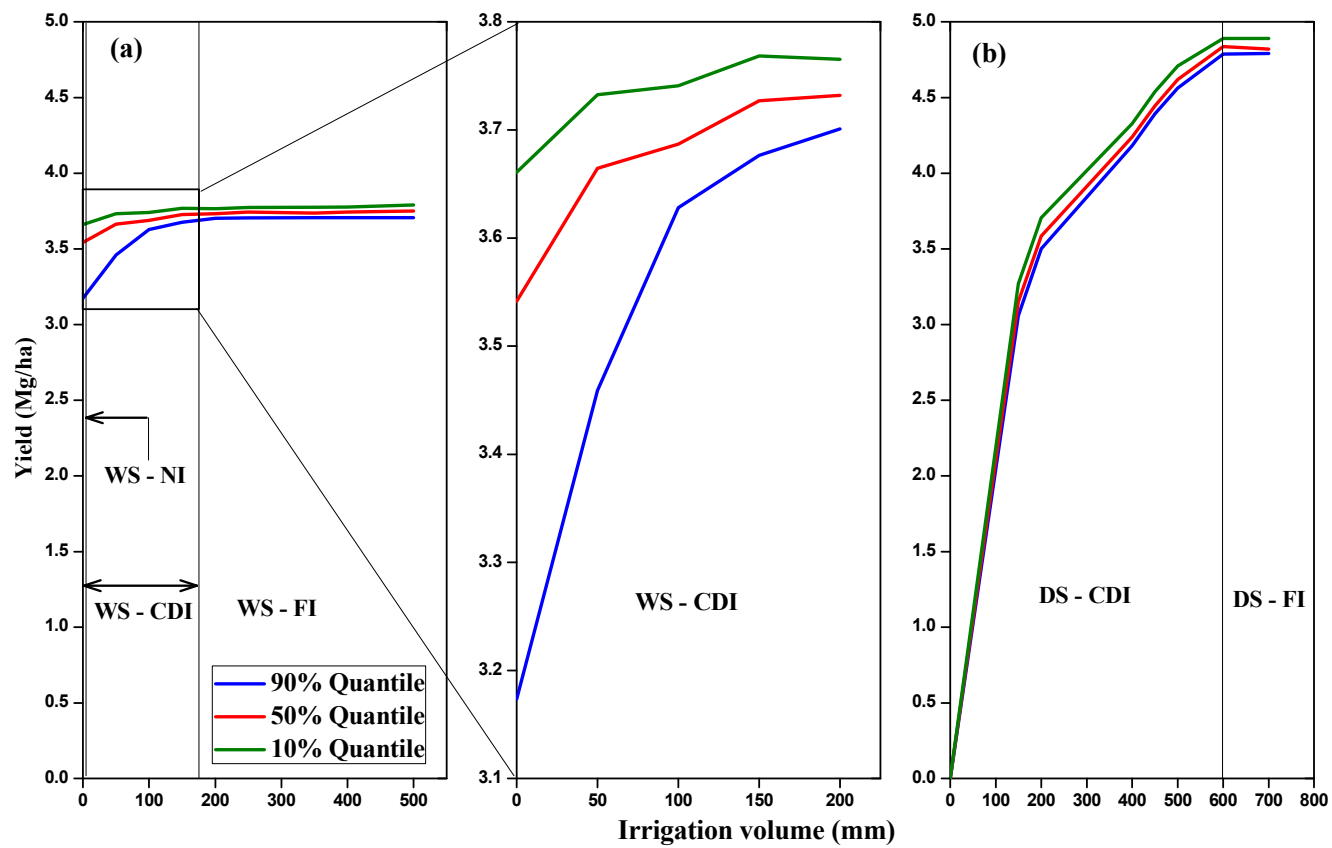

Figure 6. Stochastic crop-water production function for: (a) rainfed and supplemental irrigated systems in the wet season; and (b) optimized conventional irrigation system in the dry season for maize in Dapaong.

Figure 7 shows the detailed results of the expected yields at various amounts of supplemental irrigation water. With supplemental irrigation (WS-CDI), the rainfed yield increased from $3.48 \mathrm{Mg} / \mathrm{ha}$ to $3.74 \mathrm{Mg} / \mathrm{ha}$. The yield becomes constant when the volume of water applied is equal to or greater than $150 \mathrm{~mm}$. Then, the variability in the yields as well as the skewness decreases in absolute value. 
These results imply that supplemental irrigation is beneficial up to $150 \mathrm{~mm}$. Above this value, the advantages of supplemental irrigation (WS-FI) become insignificant. Therefore, rainfed maize crop yields may be improved in northern Togo by applying supplemental irrigation assuming that water is available.

$50 \mathrm{~mm}$

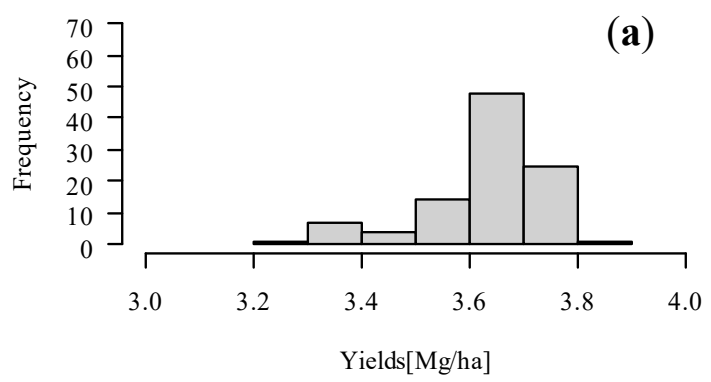

$150 \mathrm{~mm}$

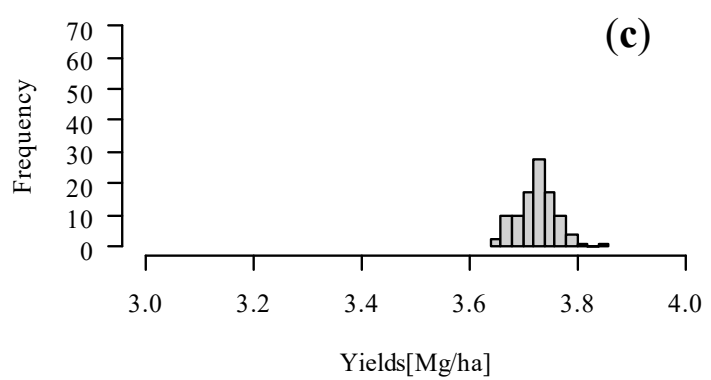

$250 \mathrm{~mm}$

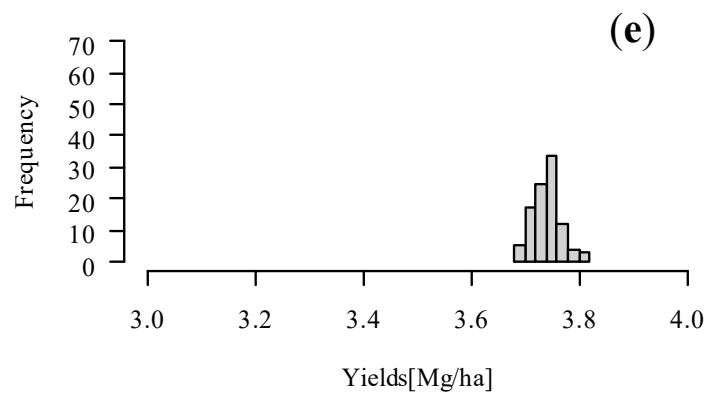

$100 \mathrm{~mm}$

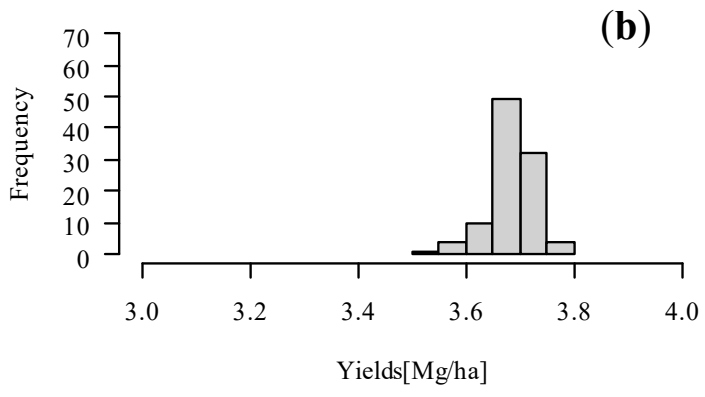

$200 \mathrm{~mm}$

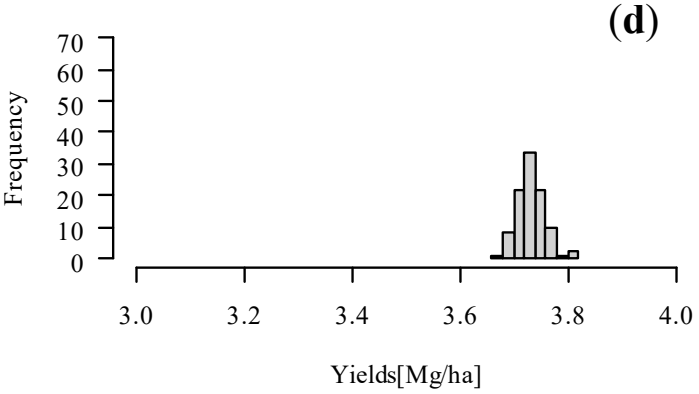

$350 \mathrm{~mm}$

(f)

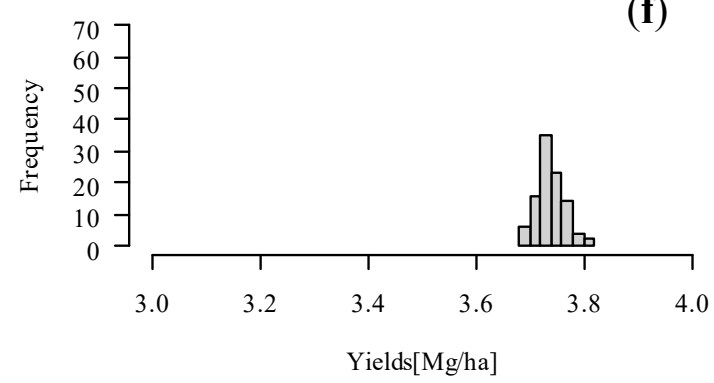

Figure 7. Histogram of distributions of expected yield using water for supplemental irrigation of maize in the wet season in Dapaong: (a) $50 \mathrm{~mm}$; (b) $100 \mathrm{~mm}$; and (c) $150 \mathrm{~mm}$ (WS-CDI); and (d) $200 \mathrm{~mm}$; (e) $250 \mathrm{~mm}$; and (f) $350 \mathrm{~mm}$ (WS-FI).

\subsubsection{Dry Season-Conventional Irrigation System (DS-CDI and DS-FI)}

Figure $6 \mathrm{~b}$ shows the stochastic crop-water production functions (SCWPF) for optimized irrigated maize crop in the dry season in northern Togo. The quantile percentage represents the probability of exceedance. Since rainfall can be ruled out, it is believed that, when the optimal full irrigation conditions are met, the variation of temperature and radiation can explain the variability in the expected crop yield. These assumptions are corroborated by the nearly symmetric distributions of the expected crop yields at full irrigation (Figure 8). These findings are supported by the results presented by Schütze and Schmitz [36]. These two parameters are part of the yield defining factors, as highlighted in the papers explaining the principles of ecology production [86]. In addition, for volumes of water lower than full irrigation, the variation in the expected crop yield can result from 
the combined effects of drought stress on crops and the climate parameters mentioned above. The maximum expected yields were $4.79 \mathrm{Mg} / \mathrm{ha}(90 \%$ quantile) and $4.89 \mathrm{Mg} / \mathrm{ha}(10 \%$ quantile) at near full irrigation $(600 \mathrm{~mm}$ ) (Figure $6 \mathrm{~b})$. The controlled deficit irrigation ranges from 0 to $600 \mathrm{~mm}$ for maize in northern Togo. The DS-CDI strategy seems to save water with an insignificant reduction in the grain yield relative to full irrigation [87-92]. Overall, growing maize crop in the dry season in northern Togo may be feasible under CDI if water is available. Irrigation is vital for improving crop yield and stabilizing crop production [93] amidst the threats of climate change [94].

$150 \mathrm{~mm}$

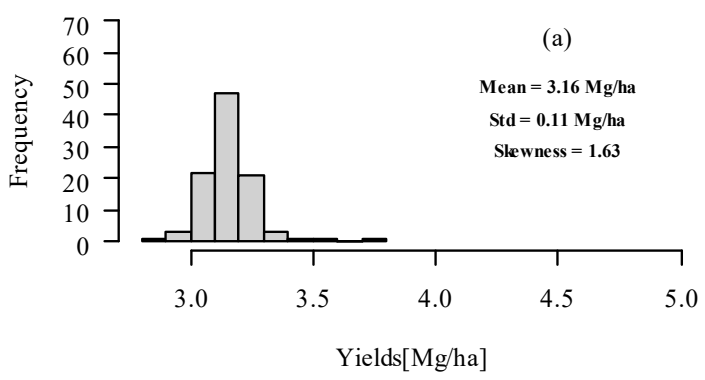

$400 \mathrm{~mm}$

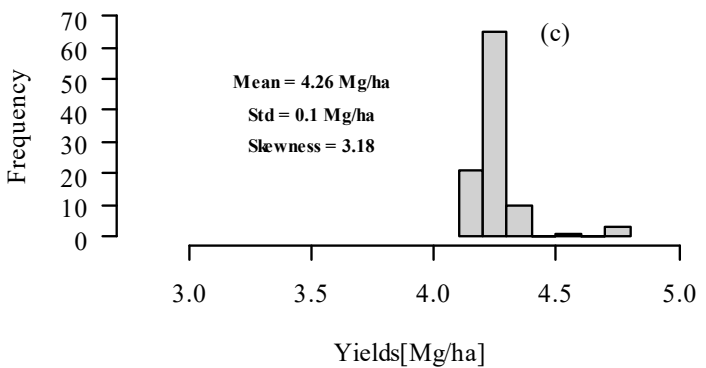

$500 \mathrm{~mm}$

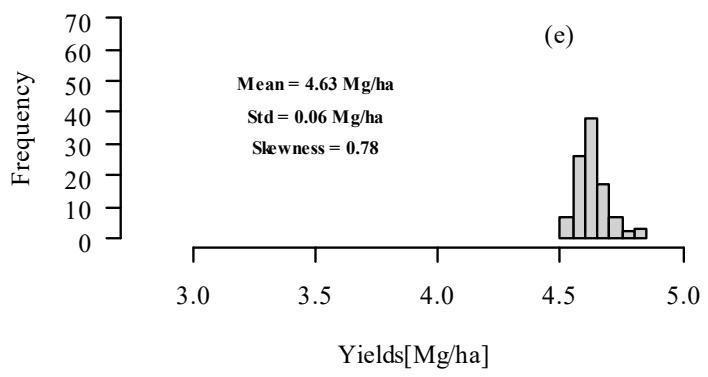

$200 \mathrm{~mm}$
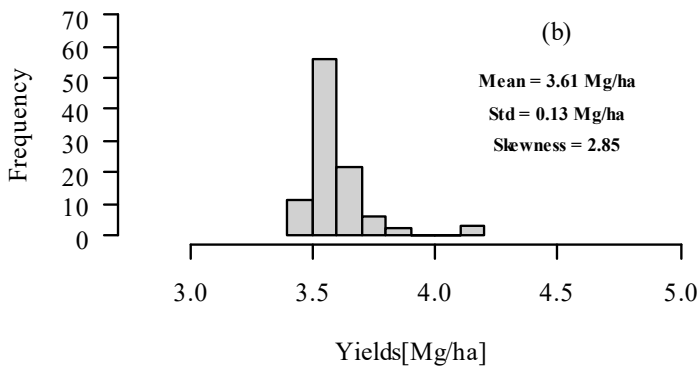

$450 \mathrm{~mm}$
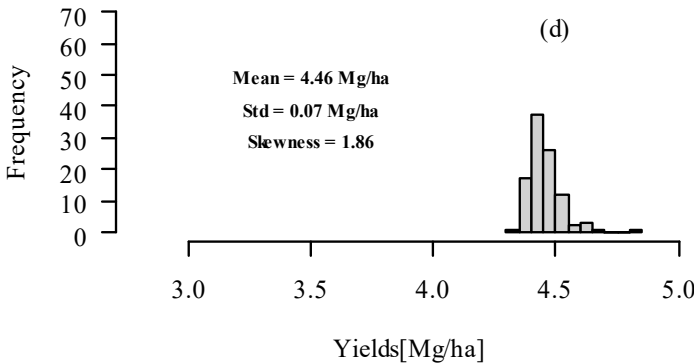

$600 \mathrm{~mm}$

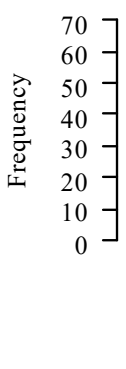

(f)

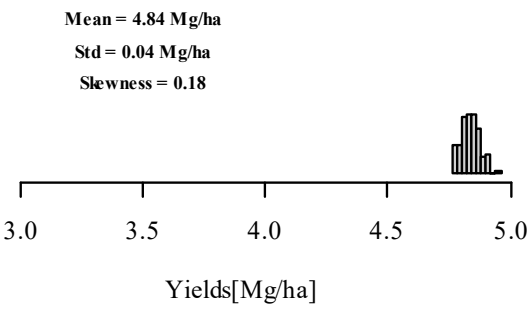

Figure 8. Histogram of distributions of expected yield using water for irrigation of maize in the dry season in Dapaong: (a) $150 \mathrm{~mm}$; (b) $200 \mathrm{~mm}$; (c) $400 \mathrm{~mm}$; (d) $450 \mathrm{~mm}$; and (e) $500 \mathrm{~mm}$ (DS-CDI); and (f) $600 \mathrm{~mm}$ (DS-FI).

In Figure 8, detailed results of the expected yields at various amounts of irrigation water are given. There is a change in the histogram distribution among the various volumes of irrigation water. The average expected yields concerning the amount of irrigation water used range from $3.16 \mathrm{Mg} / \mathrm{ha}$ to $4.84 \mathrm{Mg} / \mathrm{ha}$ at $150 \mathrm{~mm}$ and $600 \mathrm{~mm}$, respectively. With the increasing application of irrigation water (DS-CDI), the yield increases to a level at which additional water supply fails to raise the crop yield any further (around $600 \mathrm{~mm}$ ). Thus, the latter volume of water is assumed to be near full irrigation. The frequency distribution shows a positive sign for all the histograms. The coefficients of skewness 
of the expected yields for $150 \mathrm{~mm}, 200 \mathrm{~mm}$, and $400 \mathrm{~mm}$ water volumes are 1.63, 2.85, and 3.18, respectively. On the contrary, at $600 \mathrm{~mm}$ volume of water (DS-FI), the distributions of the expected yields are symmetrical. In addition, the standard deviation is relatively low for the yields at these volumes of water. Abedinpour et al. [95] reported that the AquaCrop model can predict maize yield with acceptable accuracy under variable irrigation in a semi-arid environment.

\subsection{Summary of the Discussion}

The variability in rainfall during the wet season (WS-NI) was high, inducing a considerable variability in the expected yield for rainfed conditions. The variability in the expected yield would decrease significantly if supplemental irrigation (WS-CDI or WS-FI) were applied. At the same time, supplemental irrigation would improve the expected yields and contribute to avoiding crop failure. The dry season irrigation management strategies (DS-CDI and DS-FI) would increase yield potential and decrease the variability of expected yield at the same time. Thus, the application of supplemental or dry season irrigation management strategies investigated in this study would help to enhance food availability in the West African region.

There are a few caveats that readers should keep in mind when interpreting the results of this study: The AquaCrop model in this study was calibrated with crop and soil data retrieved from previous studies conducted in the area. Thus, the conclusions derived from the outputs of the model simulation are qualitative-ranking of the irrigation management strategies assessed in the study. There are several uncertainties in the general circulation model outputs as well as crop model simulations. The uncertainties related to crop yield exist because AquaCrop assumes a disease- and pest-free environment and considers no effect of weed or extreme climate events such as flooding. Another point worth considering is that, by concluding that there is potential for deficit and supplemental irrigation for maize crop in northern Togo, we assumed that a proper soil fertility management is guaranteed, and water is available for irrigation management. Finally, it is important to note that substantial investments in irrigation infrastructure, as well as extension services to farmers, would be necessary to enhance food security in northern Togo. The calibrated crop model needs to be validated with experimental data to improve the accuracy of the resulting simulations.

\section{Conclusions}

The AquaCrop model was used to assess the potential of deficit and supplemental irrigation in the dry savannah area of northern Togo under climate variability. For this, the climate of the study area was characterized. The performance of the weather generator used to produce the long-term time series climate data for the crop simulation was also evaluated. In summary, the climate of northern Togo is unimodal with the dry season ranging from November to April. According to Köppen-Geiger's classification, the climate is hot semi-arid in northern Togo. During the dry season the mean maximum and minimum temperatures are $35^{\circ} \mathrm{C}$ and $25^{\circ} \mathrm{C}$, respectively, and the mean total rainfall is $85 \mathrm{~mm}$. In short, the performance of the LARS Weather Generator in predicting the climate of northern Togo was found satisfactory. Overall, we found that the deficit irrigation water requirement ranges from 0 to $600 \mathrm{~mm}$. The maximum expected maize grain yield that can be reached under irrigated conditions is $4.84 \mathrm{Mg} /$ ha with TZEE-W local variety. The rainfed yield can be improved from 3.48 to $3.74 \mathrm{Mg} / \mathrm{ha}$ with $150 \mathrm{~mm}$ of supplemental irrigation water. At the same time, the variability in the yield was significantly reduced. Irrigation practice in agriculture helps to lower crop yield variability as well as crop failure.

Thus, growing maize crop in the dry season in northern Togo may be feasible. In general, irrigation can help to alleviate food insecurity, while supplemental irrigation is a climate-related management practice for crop yield improvement. The latter also contributes to improving farmers' livelihood. Further maize crop genetic improvements would be needed to fine-tune the seeds to the dry season climate. Irrigation infrastructures would be needed to implement in northern Togo the irrigation management strategies investigated in this study. In addition, realistic irrigation water 
pricing and cost recovery policies should be enforced and followed by all stakeholders to maintain the irrigation infrastructures and ensure the viability of the system. Institutional reforms relevant to the development and management of irrigation systems should be made. The complicated land tenure issue in northern Togo needs to be addressed to incentivize investment in, and management of, irrigation systems. Moreover, the institutional arrangement-market and connectivity among farmers and other agents—should be improved.

To develop regional water management strategies, the adapted framework used in this study may be applied to other sites in the West African region. Field experiments are needed to validate the results of this study before the implementation of its recommendations. In addition, the framework can be extended by adding a soil variability dimension to it. The analysis can be made more comprehensive by considering farmers' socioeconomic characteristics.

Author Contributions: A.G.-T. and N.S. developed the concept and design of the numerical experiment. A.G.-T. carried out the simulations, analyzed the data, and wrote the manuscript; T.A. and N.S. critically reviewed the manuscript. All authors revised and approved the final manuscript.

Funding: This research was supported by a grant to A.G.-T. PhD scholarship under the Merit Scholarship Programme (MSP) 2015/2016 of the Islamic Development Bank (IsDB).

Acknowledgments: This research received logistical assistance from the United Nations University Institute for Integrated Management of Material Fluxes and Resources (UNU-FLORES) and Technische Universität Dresden (TU Dresden), Germany. We extend our thanks to the administration of the national meteorological service of Togo for providing us with the climate data. Our gratitude goes to the editor and anonymous reviewers whose comments and suggestions expressively contributed to the improvement of this paper. Our thanks also go to Atiqah Fairuz Salleh for her editorial input to the manuscript.

Conflicts of Interest: The authors have no competing interests to declare.

\section{Appendix A}

\section{List of Abbreviations}

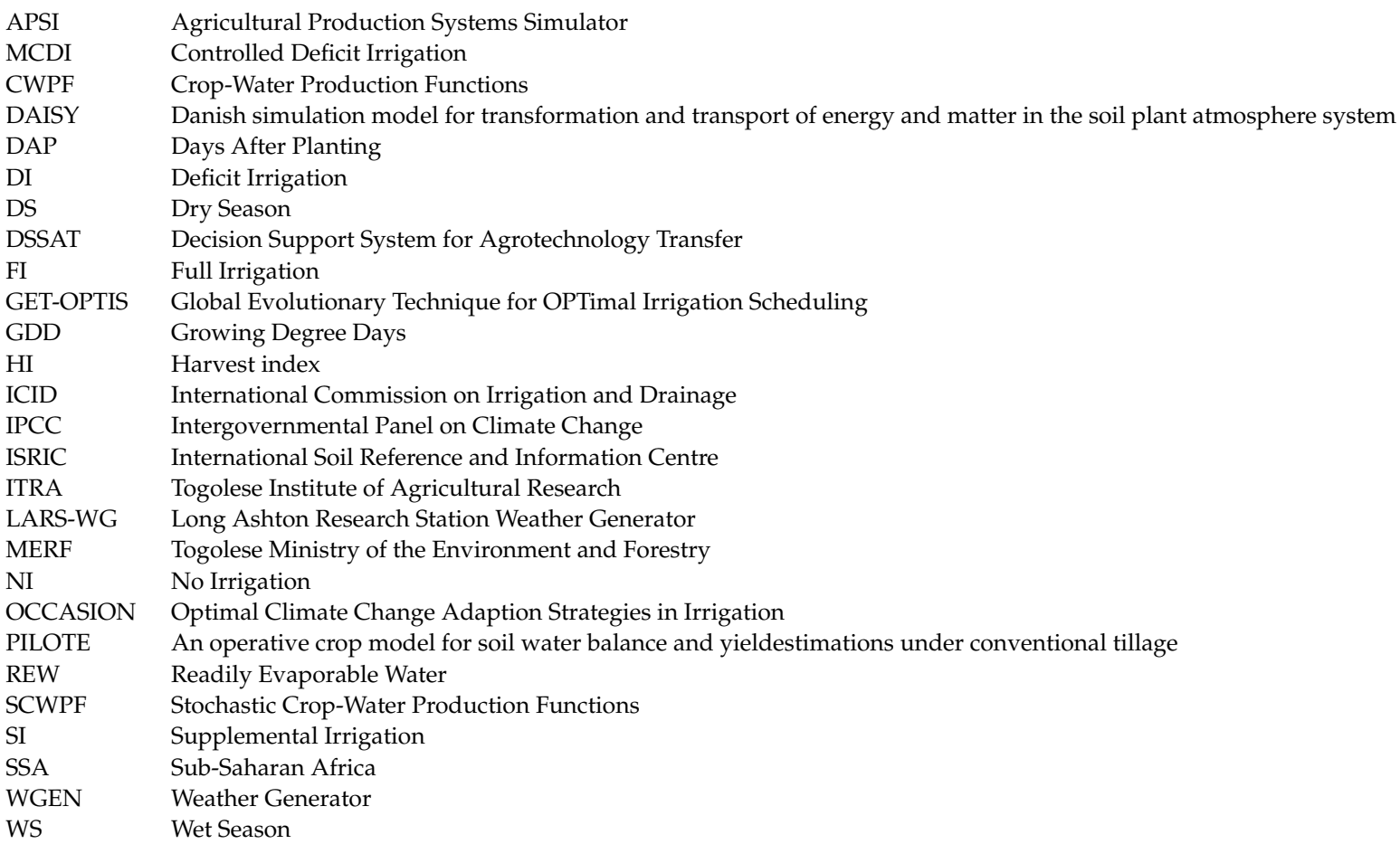

\section{References}

1. UN DESA. World Population Prospects: The 2015 Revision, Key Findings and Advance Tables; UN DESA: New York, NY, USA, 2015. 
2. UN DESA. World Population Prospects: The 2017 Revision, Key Findings and Advance Tables; UN DESA: New York, NY, USA, 2017.

3. FAO. Climate-Smart Agriculture Sourcebook; FAO: Rome, Italy, 2013; ISBN 978-92-5-107720-7.

4. Liniger, H.; Mekdaschi Studer, R.; Hauert, C.; Gurtner, M. Sustainable Land Management in Practice: Guidelines and Best Practices for Sub-Saharan Africa; TerrAfrica, World Overview of Conservation Approaches and Technologies (WOCAT) and Food and Agriculture Organization of the United Nations (FAO): Rome, Italy, 2011; ISBN 9789250000000.

5. Elliott, J.; Deryng, D.; Müller, C.; Frieler, K.; Konzmann, M.; Gerten, D.; Glotter, M.; Flörke, M.; Wada, Y.; Best, N.; et al. Constraints and potentials of future irrigation water availability on agricultural production under climate change. Proc. Natl. Acad. Sci. USA 2014, 111, 3239-3244. [CrossRef] [PubMed]

6. Edgerton, M.D. Increasing Crop Productivity to Meet Global Needs for Feed, Food, and Fuel. Plant Physiol. 2009, 149, 7-13. [CrossRef] [PubMed]

7. World Bank. World Development Report 2008: Agriculture for Development; World Bank: Washington, DC, USA, 2008.

8. Rosegrant, M.W.; Paisner, M.S.; Siet, M.; Witcover, J. 2020 Global Food Outlook; International Food Policy Research Institution: Washington, DC, USA, 2001; pp. 1-24.

9. van Ittersum, M.K.; van Bussel, L.G.J.; Wolf, J.; Grassini, P.; van Wart, J.; Guilpart, N.; Claessens, L.; de Groot, H.; Wiebe, K.; Mason-D'Croz, D.; et al. Can sub-Saharan Africa feed itself? Proc. Natl. Acad. Sci. USA 2016, 113, 14964-14969. [CrossRef] [PubMed]

10. Lobell, D.B.; Gourdji, S.M. The Influence of Climate Change on Global Crop Productivity. Plant Physiol. 2012, 160, 1686-1697. [CrossRef] [PubMed]

11. Kotir, J.H. Climate change and variability in Sub-Saharan Africa: A review of current and future trends and impacts on agriculture and food security. Environ. Dev. Sustain. 2011, 13, 587-605. [CrossRef]

12. Druyan, L.M. Studies of 21st-century precipitation trends over West Africa. Int. J. Climatol. 2011, 31, 1415-1424. [CrossRef]

13. Sarr, B. Present and future climate change in the semi-arid region of West Africa: A crucial input for practical adaptation in agriculture. Atmos. Sci. Lett. 2012, 13, 108-112. [CrossRef]

14. Ministère de l'Environnement et des Ressources Forestières (MERF). Plan d'Action National d'Adaptation aux Changements Climatiques (PANA); MERF: Lome, Togo, 2009. (In French)

15. Mcsweeney, C.; New, M.; Lizcano, G. UNDP Climate Change Country Profiles, Togo; School of Geography and Environment, Oxford University: Oxford, UK, 2009.

16. Ogounde, L.; Abotchi, T. Quelques contraintes à la croissance Agricole dans la région des Savanes du Nord-Togo. Bulletin de la société Neuchâteloise de Geographie; Société Neuchâteloise de Geographie: Neuchâtel, Switzerland, 2003. (In French)

17. Dobermann, A.; Nelson, R.; Beever, D.; Bergvinson, D.; Crowley, E.; Denning, G.; Griller, K.; d'Arros Hughes, J.; Jahn, M.; Lynam, J.; et al. Solutions for Sustainable Agriculture and Food Systems-Technical Report for the Post-2015 Development Agenda; The United Nations Sustainable Development Solutions Network (UNSDSN): New York, NY, USA, 2013.

18. Rockström, J.; Williams, J.; Daily, G.; Noble, A.; Matthews, N.; Gordon, L.; Wetterstrand, H.; De Clerck, F.; Shah, M.; Steduto, P.; et al. Sustainable intensification of agriculture for human prosperity and global sustainability. Ambio 2017, 46, 4-17. [CrossRef]

19. Godfray, H.C.J.; Garnett, T. Food security and sustainable intensification. Philos. Trans. R. Soc. Lond. B. Biol. Sci. 2014, 369, 1-10. [CrossRef]

20. Bolor, J.K. Analyse de l'état actuel de développement de l'irrigation au Togo. In Irrigation in West Africa: Current Status and $a$ View to the Future; Namara, R.E., Sally, H., Eds.; International Water Management Institute (IWMI), Colombo, Sri Lanka: Ouagadougou, Burkina Faso, 2010; pp. 305-312.

21. Jalloh, A.; Nelson, G.C.; Thomas, T.S.; Zougmoré, R.; Roy-Macauley, H. West African Agriculture and Climate Change: A Comprehensive Analysis; IFPRI Research Monograph; International Food Policy Research: Washington, DC, USA, 2013.

22. International Commission on Irrigation and Drainage (ICID). Basic Introduction: Irrigation. Available online: http:/ / www.icid.org/res_irrigation.html (accessed on 10 September 2018).

23. Rockström, J.; Hatibu, N.; Oweis, T.; Wani, S.; Barron, J.; Bruggeman, A.; Qiang, Z.; Farahani, J.; Karlberg, L. Managing Water in Rainfed Agriculture. In Water for Food, Water for Life: A Comprehensive Assessment of Water Management in Agriculture; Molden, D., Ed.; Earthscan: London, UK, 2007; pp. 315-352. 
24. Pereira, L.S. Higher performance through combined improvements in irrigation methods and scheduling: A discussion. Agric. Water Manag. 1999, 40, 153-169. [CrossRef]

25. English, M.J.; Nuss, G.S. Designing for Deficit Irrigation. J. Irrig. Drain. Div. 1982, 108, 91-106.

26. Djaman, K.; Irmak, S.; Rathje, W.R.; Martin, D.L.; Eisenhauer, D.E. Maize evapotranspiration, yield production functions, biomass, grain yield, harvest index, and yield response factors under full and limited irrigation. Am. Soc. Agric. Biol. Eng. 2013, 56, 273-293.

27. English, M. Deficit Irrigation. I: Analytical Framework. J. Irrig. Drain. Eng. 1990, 116, 399-412. [CrossRef]

28. English, M.; Raja, S.N. Perspectives on deficit irrigation. Agric. Water Manag. 1996, 32, 1-14. [CrossRef]

29. Lecler, N.L. Integrated methods and models for deficit irrigation planning. In Agricultural Systems Modeling and Simulation; Lecler, N.L., Peart, R.M., Eds.; Marcel Dekker Inc.: New York, NY, USA, 1998; pp. $283-299$.

30. Fereres, E.; Soriano, M.A. Deficit irrigation for reducing agricultural water use. J. Exp. Bot. 2006, 58, 147-159. [CrossRef] [PubMed]

31. Kögler, F.; Söffker, D. Water (stress) models and deficit irrigation: System-theoretical description and causality mapping. Ecol. Model. 2017, 361, 135-156. [CrossRef]

32. Kloss, S.; Pushpalatha, R.; Kamoyo, K.J.; Schütze, N. Evaluation of Crop Models for Simulating and Optimizing Deficit Irrigation Systems in Arid and Semi-arid Countries Under Climate Variability. Water Resour. Manag. 2012, 26, 997-1014. [CrossRef]

33. Schütze, N.; De Paly, M.; Shamir, U. Novel simulation-based algorithms for optimal open-loop and closed-loop scheduling of deficit irrigation systems. J. Hydroinformatics 2012, 14, 136-151. [CrossRef]

34. Semenov, M.A. Development of high-resolution UKCIP02-based climate change scenarios in the UK. Agric. For. Meteorol. 2007, 144, 127-138. [CrossRef]

35. Brumbelow, K.; Georgakakos, A. Consideration of Climate Variability and Change in Agricultural Water Resources Planning. J. Water Resour. Plan. Manag. 2007, 133, 275-285. [CrossRef]

36. Schütze, N.; Schmitz, G.H. OCCASION: New Planning Tool for Optimal Climate Change Adaption Strategies in Irrigation. J. Irrig. Drain. Eng. 2010, 136, 836-846. [CrossRef]

37. Jones, J.W.; Hoogenboom, G.; Porter, C.H.; Boote, K.J.; Batchelor, W.D.; Hunt, L.A.; Wilkens, P.W.; Singh, U.; Gijsman, A.J.; Ritchie, J.T. The DSSAT cropping system model J.W. Eur. J. Agron. 2003, 18, 235-263. [CrossRef]

38. Hsiao, T.C.; Heng, L.; Steduto, P.; Rojas-Lara, B.; Raes, D.; Fereres, E. Aquacrop-The FAO crop model to simulate yield response to water: III. Parameterization and testing for maize. Agron. J. 2009, 101, 448-459. [CrossRef]

39. Raes, D.; Steduto, P.; Hsiao, T.C.; Fereres, E. Aquacrop-The FAO crop model to simulate yield response to water: II. main algorithms and software description. Agron. J. 2009, 101, 438-447. [CrossRef]

40. Steduto, P.; Hsiao, T.C.; Raes, D.; Fereres, E. Aquacrop-the FAO crop model to simulate yield response to water: I. concepts and underlying principles. Agron. J. 2009, 101, 426-437. [CrossRef]

41. Hansen, S.; Jensen, H.E.; Nielsen, N.E.; Svendsen, H. DAISY: A Soil Plant System Model. Danish simulation Model for Transformation and Transport of Energy and Matter in the Soil Plant Atmosphere System; The National Agency for Environmental Protection: Copenhagen, Denmark, 1990.

42. Smith, M. CROPWAT: A Computer Program for Irrigation Planning and Management; Food and Agriculture Organization of the United Nations, Ed.; FAO irrigation and drainage paper 46; ISBN1 9251031061. Food and Agriculture Organization of the United Nations: Rome, Italy, 1992; ISBN2 9251031061.

43. Keating, B.A.; Carberry, P.S.; Hammer, G.L.; Probert, M.E.; Robertson, M.J.; Holzworth, D.; Huth, N.I.; Hargreaves, J.N.G.; Meinke, H.; Hochman, Z.; et al. An overview of APSIM, a model designed for farming systems simulation. Eur. J. Agron. 2003, 18, 267-288. [CrossRef]

44. Mailhol, J.C.; Olufayo, A.A.; Ruelle, P. Sorghum and sunflower evapotranspiration and yield from simulated leaf area index. Agric. Water Manag. 1997, 35, 167-182. [CrossRef]

45. Iqbal, M.A.; Shen, Y.; Stricevic, R.; Pei, H.; Sun, H.; Amiri, E.; Penas, A.; del Rio, S. Evaluation of the FAO AquaCrop model for winter wheat on the North China Plain under deficit irrigation from field experiment to regional yield simulation. Agric. Water Manag. 2014, 135, 61-72. [CrossRef]

46. Vanuytrecht, E.; Raes, D.; Steduto, P.; Hsiao, T.C.; Fereres, E.; Heng, L.K.; Garcia Vila, M.; Mejias Moreno, P. AquaCrop: FAO's crop water productivity and yield response model. Environ. Model. Softw. 2014, 62, 351-360. [CrossRef]

47. Department of Immigration and Citizenship (DIC). Togolese Community Profile; Department of Immigration and Citizenship, Commonwealth of Australia: Lomé, Togo, 2007. 
48. RGPH. Recensement Générale de la population et de l'habitat. Direction Générale de la Statistique et de la Comptabilité Nationale; RGPH: Lomé, Togo, 2010.

49. Ali, E. A review of agricultural policies in independent Togo. Int. J. Agric. Policy Res. 2017, 5, $104-116$. [CrossRef]

50. Poch, R.M.; Ubalde, J.M. Diagnostic of degradation processes of soils from northern Togo (West Africa) as a tool for soil and water management. In Proceedings of the Workshop for Alumni of the M.Sc. Programmes in Soil Science, Eremology and Physical Land Resources; Langouche, D., Van Ranst, E., Eds.; Workshop IC-PLR: Ghent, Belgium, 2006; pp. 187-194.

51. Institut Togolais de Recherche Agronomique (ITRA). Bien cultiver et conserver le maïs. Collection Brochures et Fiches Techniques; ITRA: Lomé, Togo, 2008. (In French)

52. Didjeira, A.; Adourahim, A.A.; Sedzro, K. Situation de référence sur les principales céréales cultivées au Togo: Maïs, Riz, Sorgho, Mil; ITRA: Lomé, Togo, 2007.

53. Desplat, A.; Rouillon, A. Diagnostic agraire dans la région des Savanes au Togo: Cantons de Nioukpourma, Naki-Ouest et Tami; Master de Recherche, Institut des Sciences et Industries du Vivant et de L'environnement, AgroParisTech: Paris, France, 2011.

54. Kottek, M.; Grieser, J.; Beck, C.; Rudolf, B.; Rubel, F. World Map of the Köppen-Geiger climate classification updated. Meteorol. Z. 2006, 15, 259-263. [CrossRef]

55. Walter, H.; Lieth, H.H.F. Klimadiagramm-Weltatlas; G. Fischer Verlag: Jena, Germany, 1967.

56. Institut National de la Statistique et des Etudes Economiques et Démographiques (INSEED). Profil de pauvreté: Togo; INSEED: Lomé, Togo, 2016.

57. Institut National de la Statistique et des Etudes Economiques et Démographiques (INSEED). Statistiques Nationales: Togo 2015. Available online: http:/ / togo.opendataforafrica.org/\# (accessed on 13 September 2018).

58. NASA POWER Project-Agroclimatology Data. Available online: https:// power.larc.nasa.gov/data-accessviewer/ (accessed on 10 September 2017).

59. Van Wart, J.; Grassini, P.; Yang, H.; Claessens, L.; Jarvis, A.; Cassman, K.G. Creating long-term weather data from thin air for crop simulation modeling. Agric. For. Meteorol. 2015, 209-210, 49-58. [CrossRef]

60. Semenov, M.A.; Brooks, R.J.; Barrow, E.M.; Richardson, C.W. Comparison of the WGEN and LARS-WG stochastic weather generators for diverse climates. Clim. Res. 1998, 10, 95-107. [CrossRef]

61. Semenov, M.A. Simulation of extreme weather events by a stochastic weather generator. Clim. Res. 2008, 35, 203-212. [CrossRef]

62. Mehan, S.; Guo, T.; Gitau, M.; Flanagan, D.C.; Mehan, S.; Guo, T.; Gitau, M.W.; Flanagan, D.C. Comparative Study of Different Stochastic Weather Generators for Long-Term Climate Data Simulation. Climate 2017, 5, 26. [CrossRef]

63. Guo, T.; Mehan, S.; Gitau, M.W.; Wang, Q.; Kuczek, T.; Flanagan, D.C. Impact of number of realizations on the suitability of simulated weather data for hydrologic and environmental applications. Stoch. Environ. Res. Risk Assess. 2018, 32, 2405-2421. [CrossRef]

64. Chakravarti, I.M.; Laha, R.G.; Roy, J. Handbook of Methods of Applied Statistics; Wiley: New York, NY, USA, 1967.

65. Semenov, M.A.; Barrow, E.M. Use of a stochastic weather generator in the development of climate change scenarios. Clim. Chang. 1997, 35, 397-414. [CrossRef]

66. Doorenbos, J.; Kassam, A.H. Yield Response to Water; FAO Irrigation and Drainage Paper No. 33; FAO: Rome, Italy, 1979.

67. Greaves, G.E.; Wang, Y.-M. Assessment of FAO AquaCrop Model for Simulating Maize Growth and Productivity under Deficit Irrigation in a Tropical Environment. Water 2016, 8, 557. [CrossRef]

68. Poss, R. Etude Morphopédologique du Nord du Togo à [au] 1/500,000; Institut français de recherche scientifique pour le développement en coopération (ORSTOM): Lomé, Togo, 1996.

69. Akumaga, U.; Tarhule, A.; Yusuf, A.A. Validation and testing of the FAO AquaCrop model under different levels of nitrogen fertilizer on rainfed maize in Nigeria, West Africa. Agric. For. Meteorol. 2017, 232, 225-234. [CrossRef]

70. IUSS Working Group WRB. World Reference Base for Soil Resources 2014, Update 2015 International Soil Classification System for Naming Soils and Creating Legends for Soil Maps; FAO: Rome, Italy, 2015.

71. Worou, K.S. Sols Dominants du Togo_Corrélation avec la Base de Référence Mondiale. Quatorzième Réunion du Sous-Comité ouest et Centre Africain de Corrélation des sols. Rapport sur les Ressources en Sols du Monde 98; Food and Agriculture Organization of the United Nations (FAO): Rome, Italy, 2002. (In French) 
72. Raes, D.; Steduto, P.; Hsiao, T.C.; Fereres, E. Chapter 2-Users guide. In Reference Manual: AquaCrop, Version 4.0; FAO, Land and Water Division: Rome, Italy, 2012; pp. 1-164.

73. Worou, S.; Saragoni, H. La Culture du Maïs de Contre Saison Est-elle Possible au Togo Meridional? Premières Conclusions d'une Experimentation sur la Station de Recherche Agronomique d'ativémé; Institut français de recherche scientifique pour le développement en coopération (ORSTOM): Lomé, Togo, 1988.

74. Geerts, S.; Raes, D.; Garcia, M.; Miranda, R.; Cusicanqui, J.A.; Taboada, C.; Mendoza, J.; Huanca, R.; Mamani, A.; Condori, O.; et al. Simulating Yield Response of Quinoa to Water Availability with AquaCrop. Agron. J. 2009, 101, 499-508. [CrossRef]

75. Salemi, H.; Amin, M.; Soom, M.; Lee, T.S.; Farhad Mousavi, S.; Ganji, A.; Kamilyusoff, M. Application of AquaCrop model in deficit irrigation management of Winter wheat in arid region. Afr. J. Agric. Res. 2011, 610, 2204-2215. [CrossRef]

76. Silvestro, P.C.; Pignatti, S.; Yang, H.; Yang, G.; Pascucci, S.; Castaldi, F.; Casa, R. Sensitivity analysis of the Aquacrop and SAFYE crop models for the assessment of water limited winter wheat yield in regional scale applications. PLoS ONE 2017, 12, 1-30. [CrossRef] [PubMed]

77. Djaman, K.; Ganyo, K. Trend analysis in reference evapotranspiration and aridity index in the context of climate change in Togo. J. Water Clim. Chang. 2015, 6, 848-864. [CrossRef]

78. Osman, Y.; Abdellatif, M.; Al-Ansari, N.; Knutsson, S.; Jawad, S. Climate Change and Future Precipitation in Arid Environment of Middle East: Case study of Iraq. J. Environ. Hydrol. 2017, 25, 1-18.

79. Assefa, S.; Biazin, B.; Muluneh, A.; Yimer, F.; Haileslassie, A. Rainwater harvesting for supplemental irrigation of onions in the southern dry lands of Ethiopia. Agric. Water Manag. 2016, 178, 325-334. [CrossRef]

80. Fosu-Mensah, B.Y. Modelling the Impact of Climate Change on Maize (Zea mays L.) YieLd under Rainfed Conditions in Sub-Humid Ghana; United Nations University-Institute for Natural Resources in Africa (UNU-INRA): Accra, Ghana, 2013.

81. Chauhan, C.P.S.; Singh, R.B.; Gupta, S.K. Supplemental irrigation of wheat with saline water. Agric. Water Manag. 2008, 95, 253-258. [CrossRef]

82. Fox, P.; Rockström, J. Supplemental irrigation for dry-spell mitigation of rainfed agriculture in the Sahel. Agric. Water Manag. 2003, 61, 29-50. [CrossRef]

83. Wakchaure, G.C.; Minhas, P.S.; Ratnakumar, P.; Choudhary, R.L. Optimising supplemental irrigation for wheat (Triticum aestivum L.) and the impact of plant bio-regulators in a semi-arid region of Deccan Plateau in India. Agric. Water Manag. 2016, 172, 9-17. [CrossRef]

84. Heng, L.K.; Hsiao, T.; Evett, S.; Howell, T.; Steduto, P. Validating the FAO AquaCrop Model for Irrigated and Water Deficient Field Maize. Agron. J. 2009, 101, 488-498. [CrossRef]

85. Stricevic, R.; Cosic, M.; Djurovic, N.; Pejic, B.; Maksimovic, L. Assessment of the FAO AquaCrop model in the simulation of rainfed and supplementally irrigated maize, sugar beet and sunflower. Agric. Water Manag. 2011, 98, 1615-1621. [CrossRef]

86. Tittonell, P.; Giller, K.E. When yield gaps are poverty traps: The paradigm of ecological intensification in African smallholder agriculture. Field Crops Res. 2013, 143, 76-90. [CrossRef]

87. Bell, J.M.; Schwartz, R.; McInnes, K.J.; Howell, T.; Morgan, C.L.S. Deficit irrigation effects on yield and yield components of grain sorghum. Agric. Water Manag. 2018, 203, 289-296. [CrossRef]

88. Greaves, G.E.; Wang, Y.-M. Effect of regulated deficit irrigation scheduling on water use of corn in southern Taiwan tropical environment. Agric. Water Manag. 2017, 188, 115-125. [CrossRef]

89. Hergert, G.W.; Margheim, J.F.; Pavlista, A.D.; Martin, D.L.; Isbell, T.A.; Supalla, R.J. Irrigation response and water productivity of deficit to fully irrigated spring camelina. Agric. Water Manag. 2016, 177, 46-53. [CrossRef]

90. Kifle, M.; Gebretsadikan, T.G. Yield and water use efficiency of furrow irrigated potato under regulated deficit irrigation, Atsibi-Wemberta, North Ethiopia. Agric. Water Manag. 2016, 170, 133-139. [CrossRef]

91. Li, X.; Kang, S.; Zhang, X.; Li, F.; Lu, H. Deficit irrigation provokes more pronounced responses of maize photosynthesis and water productivity to elevated $\mathrm{CO}_{2}$. Agric. Water Manag. 2018, 195, 71-83. [CrossRef]

92. Mustafa, S.M.T.; Vanuytrecht, E.; Huysmans, M. Combined deficit irrigation and soil fertility management on different soil textures to improve wheat yield in drought-prone Bangladesh. Agric. Water Manag. 2017, 191, 124-137. [CrossRef]

93. Lee, S.O.; Jung, Y. Efficiency of water use and its implications for a water-food nexus in the Aral Sea Basin. Agric. Water Manag. 2018, 207, 80-90. [CrossRef] 
94. Gunn, K.M.; Baule, W.J.; Frankenberger, J.R.; Gamble, D.L.; Allred, B.J.; Andresen, J.A.; Brown, L.C. Modeled climate change impacts on subirrigated maize relative yield in northwest Ohio. Agric. Water Manag. 2018, 206, 56-66. [CrossRef]

95. Abedinpour, M.; Sarangi, A.; Rajput, T.B.S.; Singh, M.; Pathak, H.; Ahmad, T. Performance evaluation of AquaCrop model for maize crop in a semi-arid environment. Agric. Water Manag. 2012, 110, 55-66. [CrossRef] 